\title{
Pennsylvanian - Early Cisuralian interglacial macrofloristic succession in Paraná Basin of the State of São Paulo
}

\author{
Mary Elizabeth Cerruti Bernardes-de-Oliveira ${ }^{a}$, Pauline Sabina Kavali a, *, 1 , \\ Sandra Eiko Mune ${ }^{a}$, Mahesh Shivanna ${ }^{\text {b}}$, Paulo Alves de Souza ${ }^{\text {b }}$, Roberto Iannuzzi ${ }^{\text {b }}$, \\ André Jasper ${ }^{\mathrm{c}}$, Amanda Hoelzel ${ }^{\mathrm{a}}$, Daiana R. Boardman ${ }^{\mathrm{b}}$, Rosemarie Rohn ${ }^{\mathrm{d}}$, \\ Fresia Ricardi-Branco ${ }^{\mathrm{e}}$ \\ a Instituto de Geociências, Universidade de São Paulo, IGc/USP. Rua do Lago, 562, CEP. 05508-080, São Paulo, SP, Brazil \\ ${ }^{\mathrm{b}}$ Instituto de Geociências, Universidade Federal do Rio Grande do Sul, IG/UFRGS, Porto Alegre, RS, Brazil \\ ${ }^{c}$ Museu de Ciências Naturais e Programa de Pós-Graduação em Ambiente e Desenvolvimento, Centro Universitário, UNIVATES, Lajeado, RS, Brazil \\ ${ }^{\mathrm{d}}$ Instituto de Geociências e Ciências Exatas, Universidade Estadual Paulista Júlio de Mesquita Filho, IGCE/UNESP, Rio Claro, SP, Brazil \\ e Instituto de Geociências, Universidade Estadual de Campinas, IGE/UNICAMP, Campinas, SP, Brazil
}

\section{A R T I C L E I N F O}

\section{Article history:}

Received 4 May 2016

Received in revised form 28 August 2016

Accepted 7 September 2016

Available online 27 September 2016

\section{Keywords:}

Macrofloral successions

Itararé group

Permo-carboniferous

Interglacial floras

Paraná Basin

Western Gondwana

\begin{abstract}
A B S T R A C T
One of the most completely preserved glacial sedimentary records from the Late Carboniferous to the Early Permian time corresponds to the Itararé Group, which presents a large outcropping thickness in the northeastern border of Paraná Basin, especially in the State of São Paulo. This unit corresponds to the base of the Gondwana I Supersequence and is composed of continental to marine glacial and interglacial deposits. Based on some macrofloristic, lithostratigraphic and palynostratigraphic data, a formal scheme of the macrofloral succession is herein proposed for this interval, comprising five associations in ascending stratigraphic order namely: (1) Dwykea-Sublagenicula-Calamospora Association (recorded in Campinas Municipality), composed of lycophyte megaspores (Sublagenicula, Trileites and Calamospora sp.) and some bryophytes (Dwykea), concerning to a coastal glacial or coastal interglacial environment; (2) Eusphenopteris-Nothorhacopteris-Botrychiopsis Association (registered in Itapeva and Buri municipalities), composed of Eusphenopteris, Nothorhacopteris, Botrychiopsis, Paracalamites spp. along with Sphenophyllum, Koretrophyllites, Noeggerathiopsis and rare Cordaicarpus and Samaropsis - concerning to an interglacial deltaic plain associated to coal forming swamps with cold temperate hydro-hygrophilous vegetation; (3) Paranocladus-Ginkgophyllum-Brasilodendron Association (registered in Monte Mor Municipality), composed of the first conifers of the Paraná Basin (Paranocladus, Paranospermum and few Buriadia-type), lycophytes (Brasilodendron, Bumbudendron), Ginkgophyllum, Noeggerathiopsis, Samaropsis and Cordaicarpus and rare Nothorhacopteris, Botrychiopsis, Koretrophyllites and Sphenophyllum, interpreted as interglacial deltaic flood plain; (4) Dwykea-Sublagenicula-Calamospora Recurrent Association (recorded in Salto Municipality), composed of bryophytes (Dwykea) and lycopod megaspores, very similar to the first association, related to a coastal glacial or coastal interglacial depositional environment with a type- tundra vegetational cover; and (5) Gangamopteris-Arberia-Stephanophyllites Association (occurring in Tietê and Cerquilho municipalities), composed of the first glossopterid leaves and fructifications of the Paraná Basin (abundant Gangamopteris, Arberia, Arberiopsis and Hirsutum) and sphenophytes (Stephanophyllites and Phyllotheca), suggested as coastal prograding or alluvial environment, of an interglacial phase at the end of the sedimentary history of the Itarare Group. The first four associations are of Pennsylvanian age while the last one is of Asselian-Sakmarian age.
\end{abstract}

(c) 2016 Elsevier Ltd. All rights reserved.

\footnotetext{
* Corresponding author.

E-mail addresses: maryeliz@usp.br (M.E.C. Bernardes-de-Oliveira), paulinesabina@gmail.com (P.S. Kavali), smune@hotmail.com (S.E. Mune), mahesh.shivanna@ufrgs.br

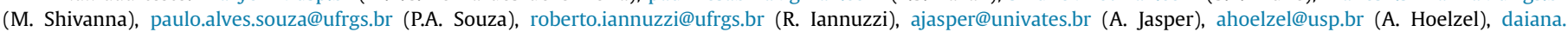
boardman@gmail.com (D.R. Boardman), rohn@rc.unesp.br (R. Rohn), fresia@ige.unicamp.br (F. Ricardi-Branco).

${ }^{1}$ Permanent address: Birbal Sahni Institute of Palaeosciences, Lucknow, India
} 


\section{Contents}

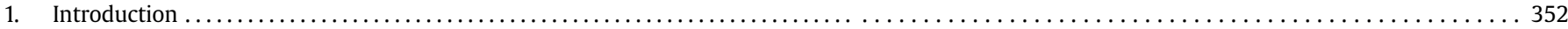

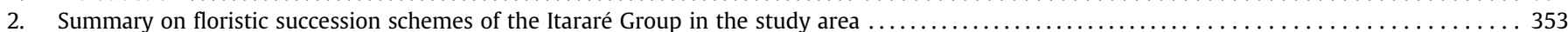

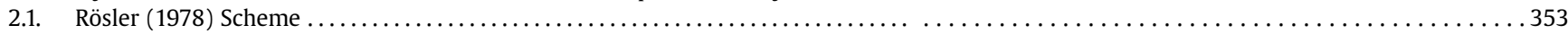

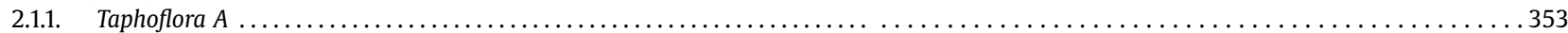

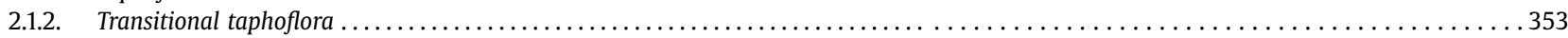

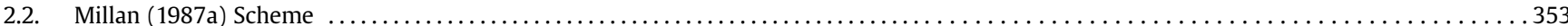

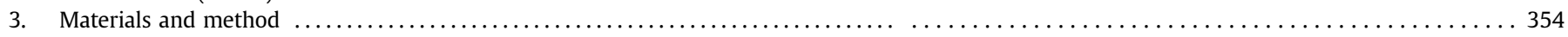

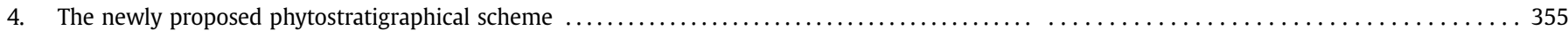

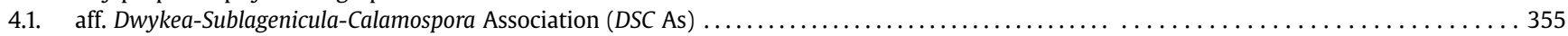

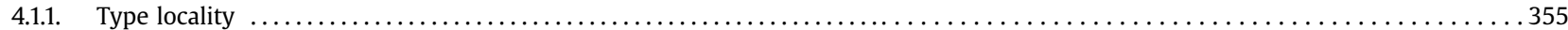

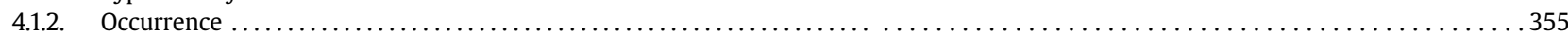

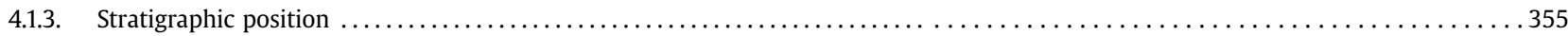

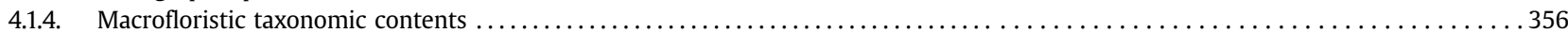

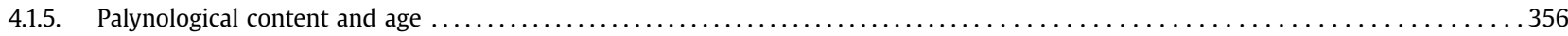

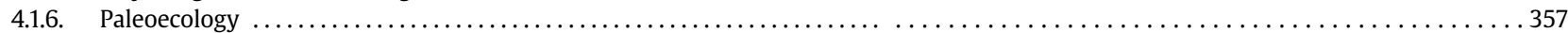

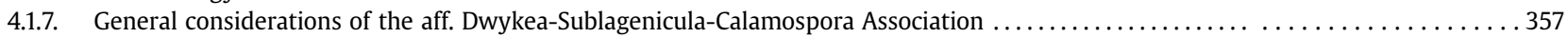

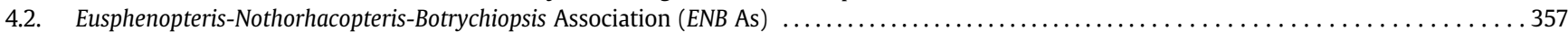

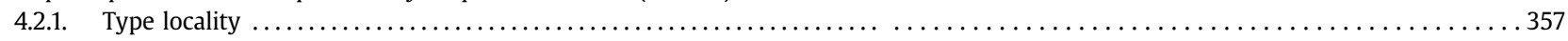

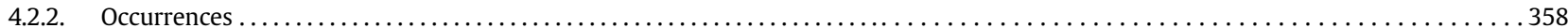

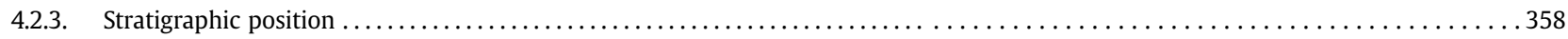

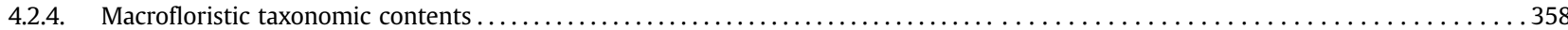

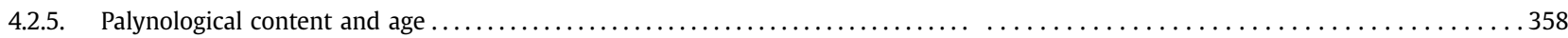

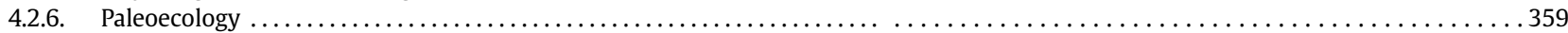

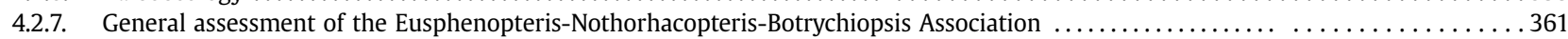

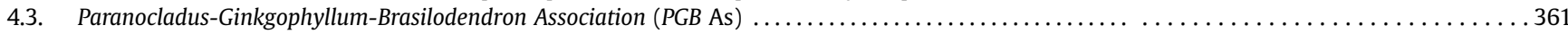

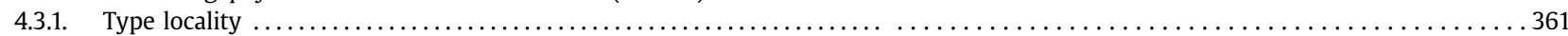

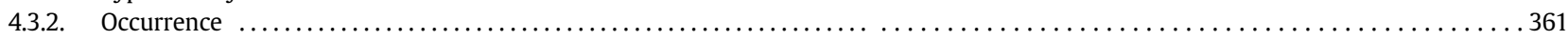

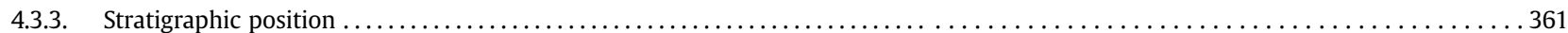

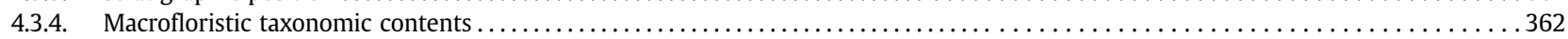

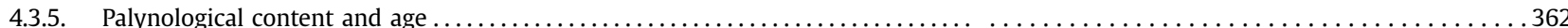

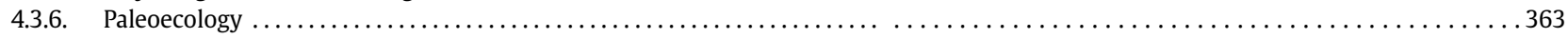

4.3.7. General considerations of the Paranocladus-Ginkgophyllum-Brasilodendron Association ........................... 365

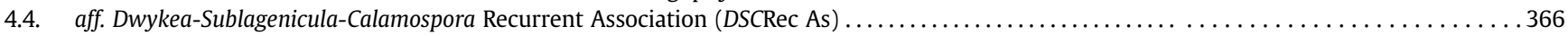

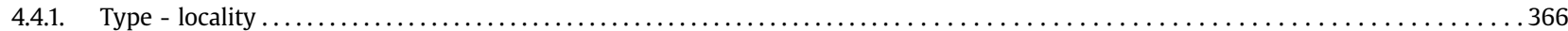

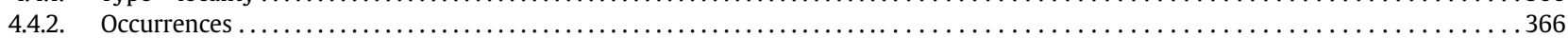

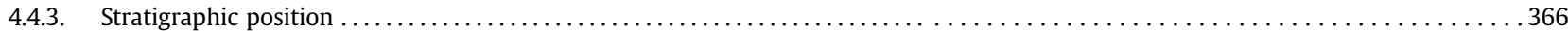

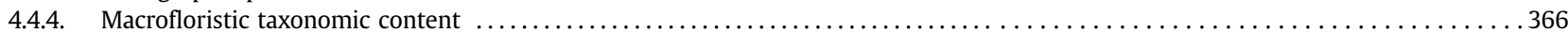

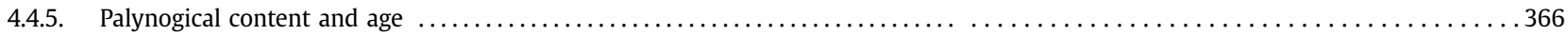

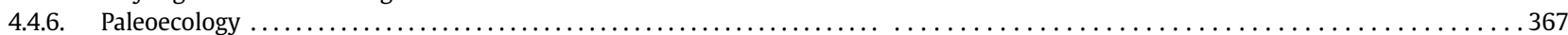

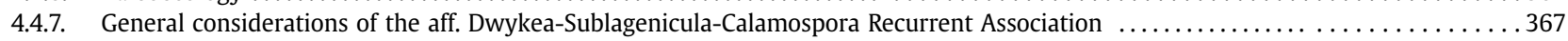

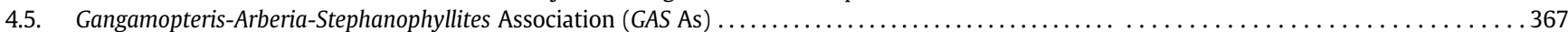

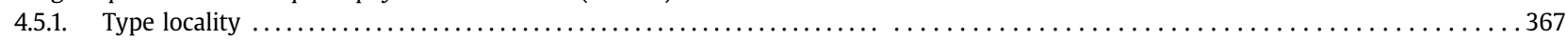

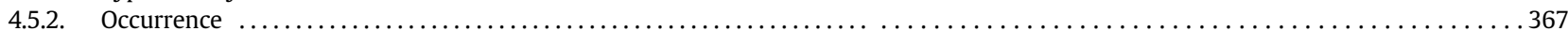

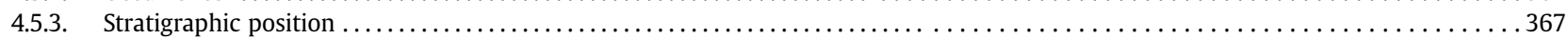

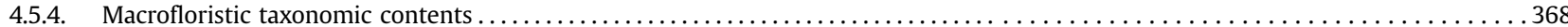

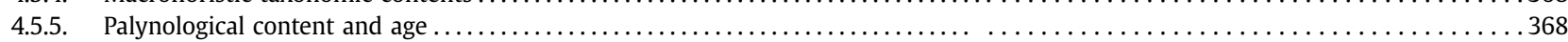

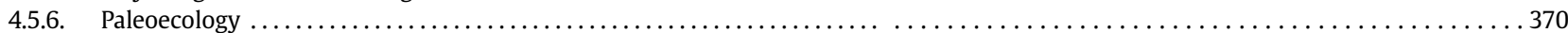

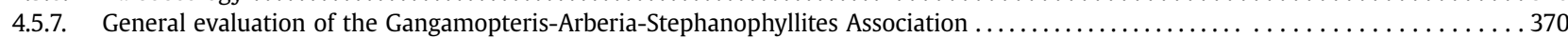

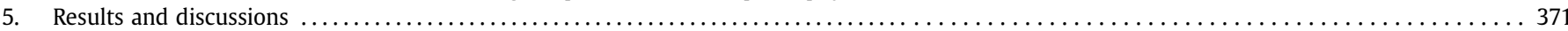

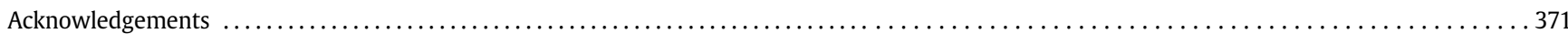

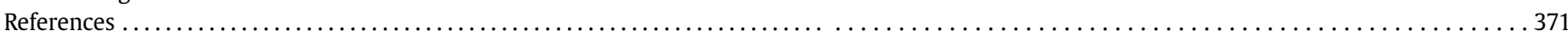

\section{Introduction}

The Gondwana continent was modified continuously in relation to its environment, climatic conditions and latitudinal positions, mainly during the Late Carboniferous-Early Permian interval, when it was closer to the South Pole (Scotese, 2000; Torsvik and Cocks, 2013). These modifications viz., variations in the sea level, paleolatitudinal position, oceanic circulation, beyond other factors, had contributed for the establishment of the well-known Late Palaeozoic Ice Age (LPIA). Vast areas of the Gondwana were under glacial cover having records of movements of glaciers from the centersouth of Africa to the southeastern region of South America, from Antarctica to the southwestern region of Australia and from Antarctica to north-northeast India (Isbell et al., 2012). The glacial climate not only caused the low temperatures in the polar or subpolar regions, but also the drying of the subtropical regions, leading to great changes in floras and accentuated global provincialism (Wnuk, 1996; Rees et al., 1999; 2002).

There are evidences of the occurrence of several interglacial/ interstadial phases when the glaciers retreated and other (fluvial, 
deltaic, lacustrine and marine) environments were established in the Gondwanan sedimentary basins during which plant associations succeeded themselves in floristic and/or evolutionary aspect.

One of the most complete sedimentary records of the LPIA in Gondwana from the Pennsylvanian to the Early Cisuralian corresponds to the Itarare Group (lower stratigraphic unit of the Tubarão Supergroup) of the Paraná Basin. It is constituted by marine and continental glacial sediments and interglacial deposits which are thicker in São Paulo State area than in other parts of the basin (Rocha-Campos and Rosler, 1978; Petri and Souza 1993). On the basis of detailed paleobotanical studies of the Itararé Group outcrops in the northeastern margin of the Paraná Basin (Brazil) and also based on known palynological data (e.g., Souza et al., 1997, 2006; Longhim et al., 2002; Souza and Callegari, 2004; Souza, 2006; Jha et al., 2012) and corresponding lithostratigraphic data, a new attempt of correlation among the interglacial floristic successions of this Gondwanan area is presented here.

Souza (2006) emphasized that the palynological content is the most efficient biostratigraphical tool for the Paraná Basin, because it is abundant and diversified, with wide distribution from the Pennsylvanian to the Middle Permian. But, the biostratigraphy based on Mississippian to Permian Gondwanan plant megafossils has been improved since the last decades of the 20 century, mostly for South America, as made evident by Archangelsky and Cúneo (1991) and Azcuy et al. (2007) indicating the potentiality of phytostratigraphic studies in the Paraná Basin.

Several biostratigraphic schemes based on plant megafossil successions were already proposed for the Gondwanan basins in Argentina (Archangelsky and Cúneo, 1984, 1991; Archangelsky et al., 1987) and for the Paraná Basin, in Brazil (Rösler, 1978; Cazzulo-Klepzig and Guerra-Sommer, 1985a,b; Millan, 1987a,b; Guerra-Sommer and Cazzulo-Klepzig, 1993; Iannuzzi et al., 2007).

The first scheme of macrofloristic successions proposed by Rösler (1978) for the Pennsylvanian to Triassic deposits of the Paraná Basin comprises seven taphofloras, of which the lowest two are concerning the Itararé Group, named (from base to top): 'A' and 'Transitional". Despite its frequent utilization, this scheme stands informal and inaccurate due to the scarcity of available taxonomic and taphofloristic data at that time and the difficulties of their lithostratigraphic and chronostratigraphic correlations. Other regional schemes were suggested for the northeastern area of the Paraná Basin in the State of São Paulo by Millan (1987a) and for the southeastern area in the State of Rio Grande do Sul, by GuerraSommer and Cazzulo-Klepzig (1993). Whereas, in the State of São Paulo, the taxonomic and biostratigraphic knowledge of the associations were yet incipient, making impossible the establishment of more accurate macrofloristic successions.

Iannuzzi and Souza (2005) described three successive informal floras from the Pennsylvanian to Early Permian interval namely, Pre-Glossopteris, Phyllotheca -Gangamopteris, Glossopteris-Brasilodendron and Polysolenoxylon-Glossopteris. They established the associations from the base to the middle part of the Itarare Group as Pre-Glossopteris Flora and the associations of the upper part of Itararé Group and basal portions of Rio Bonito Formation as Phyllotheca-Gangamopteris Flora.

Meanwhile, at the 12th International Gondwana Symposium at Mendoza, Bernardes-de-Oliveira and her team presented informally a preliminary scheme of the macrofloristic succession for this sedimentary interval occurring in the northeastern area of the Paraná Basin, State of São Paulo which was published only as an abstract in the volume of the proceedings of the symposium (Bernardes-de-Oliveira et al., 2005). Ever since this macrofloristic succession has never been formally established. Therefore the present work aims to formally establish this macrofloristic succession wherein it details the taxonomic components characteristic of each association, highlights new records on the basis of which the succession is built, also taking into consideration the palynostratigraphic data from this sedimentary interval of this part of the State. Further, integrating macrofloral data with palynological and lithological data the paleoecology has been reconstructed.

\section{Summary on floristic succession schemes of the Itararé Group in the study area}

In a practical sense, the deposits of the Itarare Group in the northeastern border of the Paraná Basin are restricted to the State of Sao Paulo. Therefore, we will address here only the phytostratigraphic schemes that concern more specifically to the fossiliferous localities or outcrops situated in this state (Fig. 1).

\subsection{Rösler (1978) Scheme}

Rösler (1978) established the Early Gondwanan paleofloristic succession for the Paraná Basin wherein he recognized only two levels for the Tubarão Supergroup in the State of São Paulo, Table 1:

\subsubsection{Taphoflora A}

It is characterized by the dominance of Paracalamites, Paranocladus, Lycopodiopsis and Samaropsis genera, the presence of Botrychiopsis, Noeggerathiopsis, Buriadia, etc. and absence, at least, apparently of Gangamopteris and Glossopteris.

Stratigraphic position: Itararé Group.

Type-locality: Volpe Ranch (previously named as Mine Ranch), municipality of Monte Mor (São Paulo State).

Age: Probable Stephanian "Pre-Glossopterids", according to Rösler (1978) who considered this taphoflora as records of the oldest paleoflora in the studied sequence.

\subsubsection{Transitional taphoflora}

It is characterized by the presence of the oldest megafossils of glossopterid leaves (Gangamopteris and possible Rubidgea, now included in Gangamopteris according to Tybusch and Iannuzzi, 2008 and Hoelzel, 2014) from Paraná Basin, associated with some elements of Paranocladus, Noeggerathiopsis and Phyllotheca.

Stratigraphic position: upper part of the Itararé Group.

Type localities: Cerquilho (São Paulo State) and Acampamento Velho (Rio Grande do Sul State).

Age: Putative early Sakmarian age, after Rösler (1978) who considered it as a transitional taphoflora between the Taphoflora "A" (Pre-Glossopterids flora, Stephanian) and the Taphoflora "B" (rich in Glossopterids in association with abundant northern elements such as Asterotheca, Pecopteris spp. and Annularia of the Sakmarian to early Artinskian age, occurring in the São João do Triunfo Member of the Rio Bonito Formation in Paraná State).

\subsection{Millan (1987a) Scheme}

With the further increase in the knowledge of palaeobotanical occurrences in the following decade, Millan (1987a) presented a phytostratigraphic scheme for the Itararé Group in the São Paulo State, which can be resumed from the base to the top as in Table 2.

Millan (1987a) recognized three floristic stages:

Montemorense stage - The lowermost stage is compared to the macrofloristic zone Trampeaderense of the Paganzo Basin, in Argentina (Azcuy and Jelin, 1980), which is equivalent to the preglossopterids taphofloras or "Taphoflora A" (sensu Rösler, 1978) of the Paraná Basin. The association of Botrychiopsis cf. B. weissiana (ancestral) with the $B$. cf. $B$. plantiana (descendent) in the Monte Mor taphoflora and the corresponding lithostratigraphic position of the Itu Formation (considered then lower portion of the Itararé 


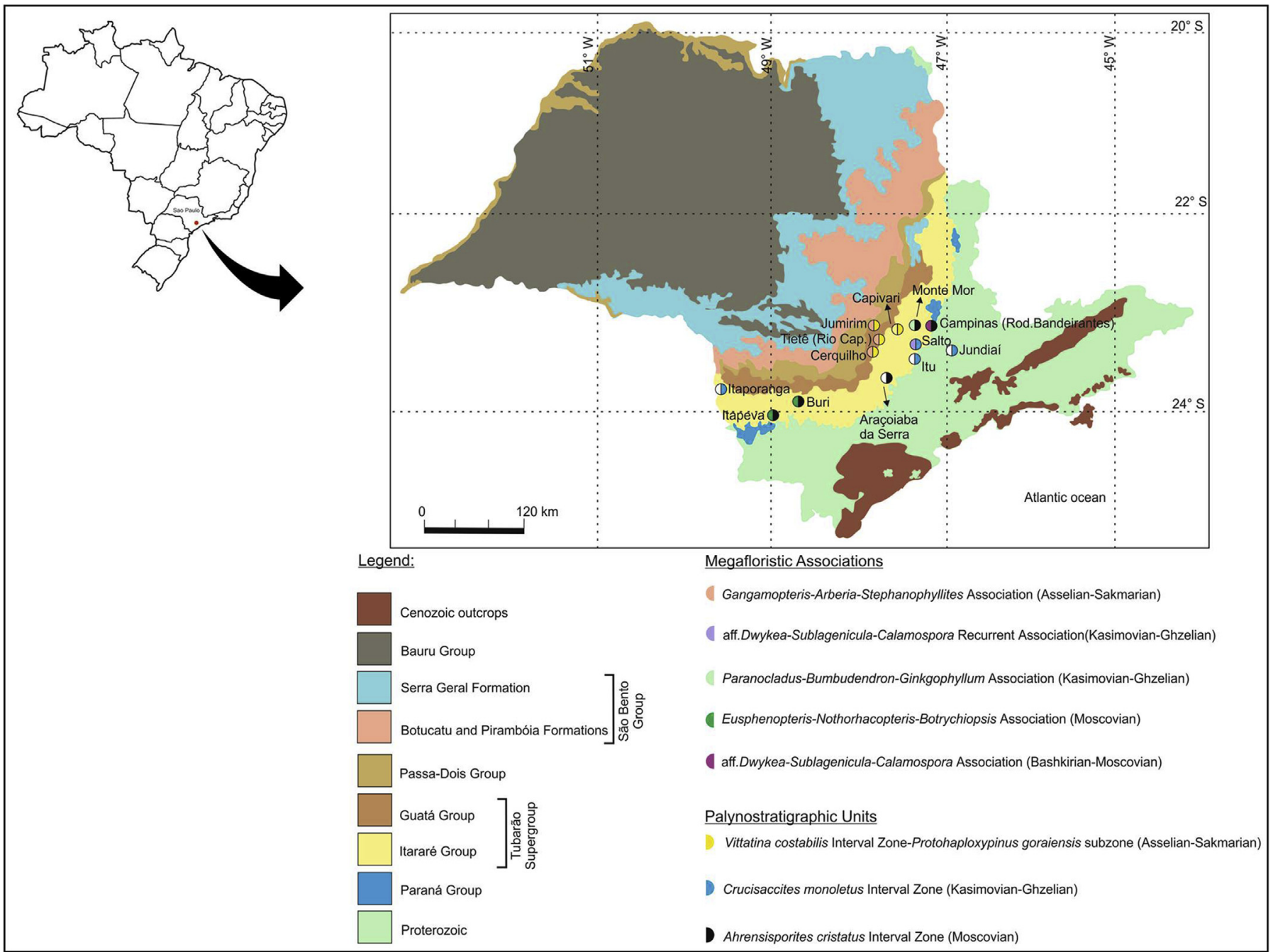

Fig. 1. Map of the State of São Paulo showing the principle occurrence locations of macrofloristic associations.

Group) were arguments for Millan (1987a) to consider the age of the Montemorense stage as transitional Westphalian - Stephanian.

Medianense stage - An intermediate stage comprised of three floristic substages viz., Buriense, Cesario-langense and Itapevense. Without reliable evidence, the author considered this intermediate stage not presenting sufficient floristic affinities with "taphoflorules" older or younger to it. Further, he considered the sequence of the substages to be provisional due to the incipient floristic knowledge, recognizing that, the absence of data in those taphofloras did not permit to characterize and distinguish very well one from the other.

Cerquilhense stage. The uppermost floristic stage occurring as the Itapema Ranch taphoflora (Cerquilho Velho County, in Cerquilho municipality) recorded the rise of the glossopterids (as
Rubidgea, Gangamopteris, etc) in the State of São Paulo, a group absent in the lower strata. Based on the absence of the genus Glossopteris and presence of microflora in Cerquilho, Millan (1987a) considered it to be similar to the Pre-Striatiti palynozone of Arai (1980). Further he correlated Cerquilhense stage to the basal part of the macrofloristic zone Lubeckense A or basal part of the Bajo de Veliz Formation of the Paganzo Basin in Argentina suggesting a Stephanian age to it and also suggested this stage to be older than Acampamento Velho in the state of Rio Grande do Sul, which is of early Permian age.

\section{Materials and method}

Taxonomic revision of the taphofloras already known and the

Table 1

Phytostratigraphic scheme for the Itararé Group in the Northeastern border of the Paraná Basin, after Rösler (1978).

\begin{tabular}{|c|c|c|c|}
\hline $\begin{array}{l}\text { Floristic } \\
\text { stage }\end{array}$ & Type taphofloras & Characteristic elements & Age \\
\hline $\begin{array}{l}\text { Transitional } \\
\text { Taphoflora }\end{array}$ & $\begin{array}{l}\text { Cerquilho (São Paulo State) and Acampamento } \\
\text { Velho (Rio Grande do Sul State). }\end{array}$ & $\begin{array}{l}\text { Presence of the oldest megafossils of glossopterid leaves (Gangamopteris and some forms } \\
\text { previously considered Rubidgea) associated with elements of Paranocladus, Noeggerathiopsis } \\
\text { and Phyllotheca from Paraná Basin. }\end{array}$ & $\begin{array}{l}\text { Early } \\
\text { Sakmarian }\end{array}$ \\
\hline Taphoflora A & $\begin{array}{l}\text { Volpe Ranch (previously Mine } \\
\text { Ranch),municipality of Monte Mor (São Paulo } \\
\text { State). }\end{array}$ & $\begin{array}{l}\text { Dominant genera: Lycopodiopsis, Paranocladus,Paracalamites, and Samaropsis; } \\
\text { Common genera: Botrychiopsis, Noeggerathiopsis, Buriadia, etc. and } \\
\text { Absence: at least, apparently of the genera Gangamopteris and Glossopteris. }\end{array}$ & Stephanian \\
\hline
\end{tabular}


Table 2

Phytostratigraphic scheme for the Itararé Group in the Northeastern border of the Paraná Basin, after Millan (1987a).

\begin{tabular}{|c|c|c|c|c|}
\hline Floristic stage & Sub-stage & Type taphofloras & Characteristic elements & Age \\
\hline \multirow[t]{2}{*}{$\begin{array}{l}\text { Cerquilhense } \\
\text { stage }\end{array}$} & & $\begin{array}{l}\text { Mine Road } \\
\text { (Alliance County) }\end{array}$ & Phyllotheca, Paracalamites, Cordaites. & Stephanian/Sakmarian \\
\hline & & Itapema Ranch & $\begin{array}{l}\text { First Glossopterids (Gangamopteris spp.)-Proto Glossopterids (Rubidgea } \\
\text { obovata, R.lanceolata, R.lanceolata var. truncata, R.itapevense, Fertiliger } \\
\text { Brasiloides), Phyllotheca, Paracalamites, Cordaites, Stephanophyllites. }\end{array}$ & Stephanian/Sakmarian \\
\hline \multirow[t]{3}{*}{$\begin{array}{l}\text { Medianense } \\
\text { stage }\end{array}$} & Itapevense & Santa Marta Farm & $\begin{array}{l}\text { Botrychiopsis plantiana, Paracalamites australis, Sphenophyllum, Cordaites, } \\
\text { Cordaicarpus. }\end{array}$ & Upper Stephanian \\
\hline & Cesario-Langense & Santa Catarina Farm & $\begin{array}{l}\text { Stem and leaves of lycophytes, with roots in situ. Palynology similar to } \\
\text { Buriense substage }\end{array}$ & Lower Stephanian \\
\hline & Buriense & $\begin{array}{l}\text { Paineira Farm/Ribeirão } \\
\text { da Enxovia }\end{array}$ & $\begin{array}{l}\text { Nothorhacopteris with } 70-80 \% \text { of trilete spores (Vallatisporites, } \\
\text { Kraeuselisporites, Cingulatisporites, Cirratriradites, Acanthotriletes), } \\
5 \% \text { of monoletes and } 20 \% \text { of monosaccate pollen grains. }\end{array}$ & Lower Stephanian \\
\hline Montemorense stage & & $\begin{array}{l}\text { Mine Ranch (now } \\
\text { Volpe Ranch) }\end{array}$ & $\begin{array}{l}\text { Lepidodendron pedroanum, Lycopodiopsis derby, Brasilidendron pedroanum, } \\
\text { Nothorhacopteris sp A, N.sp B, Botrychiopsis cf. plantiana, B.cf. weissiana, } \\
\text { Adiantites sp, Ginkgophyllum sp, Paranocladus? fallax, Buriadia sp, } \\
\text { Paracalamites australis, P. levis, P. montemorensis and megaspores: } \\
\text { Trileites, Lagenoisporites, Calamospora, Duosporites, Setosisporites and } \\
\text { absence of Glossopterids. }\end{array}$ & Westphalian/Stephanian \\
\hline
\end{tabular}

discovery of new macrofloristic occurrences and their taxonomic identification were being done by Amaral (2000), Amaral and Ricardi-Branco (2004), Amaral et al. (2004), Rohn and Lages (2000), Lages et al. (2002a,b), Rohn et al. (2000), Zampirolli (2001), Zampirolli et al. (1999a,1999b), Longhim (2003), and Mune (2005). Based on these studies, Bernardes-de-Oliveira et al. (1999, 2000, 2001a, 2001b, 2005) were gradually improving the macrofloristic scheme of the Itararé Group in the State of São Paulo, while several local palynofloristic studies were being done by Souza (1996, 2000), Zampirolli et al. (2000), Callegari (2001), Amaral et al. (2001),Souza et al. (2006, 2010), Longhim et al. (2002), Longhim (2003), Mune et al. (2004) and Jha et al. (2012).

Most part of these studies culminated in the palynostratigraphic zonation presented by Souza (2006) for the PennsylvanianCisuralian strata of the Itarare Group at the Northeastern Paraná Basin based on subsurface and outcrop sampling data from São Paulo and Paraná states. On the other hand, based on the paleobotanical data obtained from outcrops located in the State of São Paulo, a biostratigraphic macrofloristic succession is formally recognized and presented as follows, which is composed of five interglacial associations based on the vertical distribution of the identified macrofloral taxa, their relative frequency and the corresponding palynostratigraphic zonation (Table 3).

In order to establish the stratigraphic succession of macrofloras in the northeastern part of the Paraná Basin the following aspects were taken into consideration.

1 This scheme is based on lithostratigraphy and lithofacies recognized by authors who studied the succession of beds or facies after careful analysis on the field in different places. Souza Filho (1986) for the area of Campinas until Capivari; Ciantelli Jr. et al. (1983), Cabral and Motta (1985), Silva (1994) for the area of Buri and Itapeva in the south of the State; Gama et al. (1992a, 1992b) for the area of Itu and Salto; and Massoli et al. (1986), Martini and Rocha-Campos (1991),Santos et al. (1996) and França et al. (1996) for the area of Cerquilho. It is also based on the observations made by some of the authors of this work such as presence of diamictites situated below and above the coal or fossiliferous beds in Mont Mor area.

2. The scheme is also based on the taxonomic composition of each macroflora taking into consideration the presence and absence of important plant groups and their first and last appearance or reappearance.
3. The scheme is also based on comparison with the palynostratigraphic zones established by Souza and Marques-Toigo (2005) and Souza (2006) because, although the succession is based on macroflora, the strongest arguments of the palynomorph associations in a completely continental sequence must also be considered.

\section{The newly proposed phytostratigraphical scheme}

\section{1. aff. Dwykea-Sublagenicula-Calamospora Association (DSC As)}

It is the oldest of all macrofloristic associations known in the northeastern margin of the Paraná Basin.

\subsubsection{Type locality}

This association occurs in the $96 \mathrm{~km}$ of the Bandeirantes Highway in the Campinas Municipality and it is hitherto the only known taphoflora in this biostratigraphic level. Its study was developed by Amaral et al. (2004).

\subsubsection{Occurrence}

This association is recognized only in the type-locality.

\subsubsection{Stratigraphic position}

The phytofossiliferous assemblage contains abundant megaspores, some bryophyte leafy gametophytes (Amaral et al., 2004), unidentifiable stems and palynomorphs (Souza et al., 2006) preserved in a massive dark grayish mudstone, intensely bioturbated and rhythmically interlaid with fine sandstones. The mudstone outcrop of the $96 \mathrm{Km}$ of the Bandeirantes Highway corresponds to the lithostratographic Unit II of Souza Filho (1986) which was stratigraphically positioned in the basal portion of the Itararé Group. This Unit II has its lower contact directly on the crystalline basement and it is intermixed laterally with the Unit I (fining upward sandstones), covering Unit I with siltstones and shales in its upper part. Its upper contact with the Unit III (mudstones and diamictites) is gradational. The Hortolândia (SP) marine fossil fauna, composed of Phestia, Nuculopsis, Edmondia (?) and indeterminate pholadomids (Rocha-Campos and Rosler, 1978), is positioned in the Unit II and cannot be considered as the lateral extension of the Capivari (SP) fauna (composed of Peruvispira delicata, Attenuatella, Limipecten capivariensis, Rhynchopora grossopunctata, Streblopteria sp. and Phestia sp. considered early 
Table 3

The Macrofloristic Associations of the Itararé Group on the Northeastern margin of the Paraná Basin and their paleobotanical characteristics.

\begin{tabular}{|c|c|c|c|c|}
\hline Macrofloristic association & Characteristics & Age & Paleoecology & Occurrences \\
\hline $\begin{array}{l}\text { GAS Association Gangamopteris- } \\
\text { Arberia- } \\
\text { Stephanophyllites }\end{array}$ & $\begin{array}{l}\text { Abundant taxa: } \\
\text { Gangamopteris } \\
\text { Paracalamites } \\
\text { Phyllotheca } \\
\text { Stephanophyllites } \\
\text { Exclusive taxon: } \\
\text { Stephanophyllites } \\
\text { sanpaulensis } \\
\text { Taxa with first appearance: } \\
\text { Arberia } \\
\text { Arberiopsis } \\
\text { Hirsutum }\end{array}$ & Asselian/Sakmarian & $\begin{array}{l}\text { Communities of interglacial interval composed by: } \\
\text { Hygrophilous: sphenophytes living on the margins of } \\
\text { interdistributarian channels and on deltaic plains. } \\
\text { Mesophilous: proto-glossopterids, gangamopterids, } \\
\text { and cordaitales, living on fluviatile plains not so far } \\
\text { from the margins. }\end{array}$ & $\begin{array}{l}\text { Cerquilho and } \\
\text { Tietê }\end{array}$ \\
\hline $\begin{array}{l}\text { DSC Rec Association Recurrent } \\
\text { aff. Dwykea- } \\
\text { Sublagenicula- } \\
\text { Calamospora }\end{array}$ & $\begin{array}{l}\text { Frequent forms: } \\
\text { Stems not identified } \\
\text { Taxa recurrent: } \\
\text { aff. Dwykea }\end{array}$ & $\begin{array}{l}\text { Late Bashkirian to } \\
\text { Moscovian/Late } \\
\text { Moscovian to Ghzelian }\end{array}$ & $\begin{array}{l}\text { Probably coastal vegetation like Tundra. This } \\
\text { association could be related to the beginning } \\
\text { of glacier retreat. }\end{array}$ & Itu and Salto \\
\hline $\begin{array}{l}\text { PGB-Association } \\
\text { Paranocladus- } \\
\text { Ginkgophyllum- } \\
\text { Brasilodendron }\end{array}$ & $\begin{array}{l}\text { Abundant taxa: } \\
\text { Paranocladus } \\
\text { Paranospermum } \\
\text { Brasilodendron } \\
\text { Ginkgophyllum } \\
\text { Paracalamites } \\
\text { Frequent tax: } \\
\text { Bumbudendron } \\
\text { Noeggerathiopsis } \\
\text { Buriadia } \\
\text { Samaropsis } \\
\text { Cordaicarpus }\end{array}$ & $\begin{array}{l}\text { Late Bashkirian to } \\
\text { Moscovian/Late } \\
\text { Moscovian to Ghzelian }\end{array}$ & $\begin{array}{l}\text { Communities of interglacial interval composed by: } \\
\text { Hydro-hygrophilous: lycophytes and sphenophytes } \\
\text { Hygro-mesophilous: progymnosperms, pteridosperms } \\
\text { and cordaitales Xerophilous: conifers in submountain } \\
\text { environment. interglacial landscape under a moderate } \\
\text { cold climate. }\end{array}$ & Monte Mor \\
\hline $\begin{array}{l}\text { ENB-Association } \\
\text { Eusphenopteris- } \\
\text { Nothorhacopteris- } \\
\text { Botrychiopsis }\end{array}$ & $\begin{array}{l}\text { Exclusive taxon: } \\
\text { Eusphenotperis } \\
\text { Abundant taxa: } \\
\text { cf. Eusphenopteris sp. } \\
\text { Botrychiopsis plantiana } \\
\text { Nothorhacopteris cf. } \\
\text { N.argentinica } \\
\text { Paracalamites levis } \\
\text { Paracalamites australis } \\
\text { Paracalamites montemorensis } \\
\text { Sphenophyllum rhodesii } \\
\text { Cordaicarpus zeilleri } \\
\text { Taxa with first appearance: } \\
\text { Botrychiopsis, Sphenophyllum, } \\
\text { Nothorhacopteris }\end{array}$ & $\begin{array}{l}\text { Late Bashkirian to } \\
\text { Moscovian }\end{array}$ & $\begin{array}{l}\text { Communities of an interglacial interval composed by: } \\
\text { Hygro-mesophilous: represented by pteridosperms or } \\
\text { progymnosperms Meso-xerophilous: } \\
\text { cordaitales (Noeggerathiopsis) probably lived in } \\
\text { higher areas not so far from the margins. climate } \\
\text { under a moderate cold. }\end{array}$ & Itapeva and Buri \\
\hline $\begin{array}{l}\text { DSC-Association aff. } \\
\text { Dwykea- } \\
\text { Sublagenicula- } \\
\text { Calamospora }\end{array}$ & $\begin{array}{l}\text { Frequent forms: } \\
\text { Stems not identified } \\
\text { Abundant taxa: } \\
\text { Sublagenicula brasiliensis, } \\
\text { Sublagenicula sinuata, Trileites } \\
\text { tenuis, Calamospora sp. } \\
\text { Taxa with first appearance: } \\
\text { aff. Dwykea }\end{array}$ & $\begin{array}{l}\text { Late Bashkirian to } \\
\text { Moscovian }\end{array}$ & $\begin{array}{l}\text { Probably coastal vegetation like Tundra. This } \\
\text { association could be related to the beginning } \\
\text { of glacier retreat. }\end{array}$ & $\begin{array}{l}\text { Campinas } \\
\text { (Rod.Bandeirantes } \\
\text { Km 96) }\end{array}$ \\
\hline
\end{tabular}

Permian), as suggested by those authors. The Capivari fauna is included in the Unit III according to Souza Filho (1986). The lower stratigraphic positioning of this taphoflora is confirmed by palynostratigraphic data of Souza et al. (2006).

\subsubsection{Macrofloristic taxonomic contents}

The bryophyte remains were identified by Amaral et al. (2004) as belonging to Class Bryopsida, aff. Dwykea sp. presenting many features of this genus which occurs in the tillites of the Dwyka Group of the Karroo Basin (Lower Permian) of South Africa (Anderson and Anderson, 1985).

The bryophyte gametophyte remains of the Itararé Group contain caulids covered by phyllids. On the axil of one of these phyllids a sporophyte is preserved (Amaral et al., 2004).These few bryophytic macro remains occur associated with a huge quantity of megaspores of the species Sublagenicula brasiliensis (the most abundant),
Sublagenicula sinuata, Calamospora sp. and Trileites tenuis (Fig. 2) and some unidentifiable stems (Amaral and Ricardi-Branco, 2004).

\subsubsection{Palynological content and age}

According to Souza (2006), the palynological content of this unit comprises: Psomospora detecta; Retusotriletes nigritellus; Lundbladispora braziliensis; L. riobonitensis; Kraeuselisporites volkheimerii; K. punctatus; Vallatisporites vallatus; V.drybrookensis; Cristatisporites inordinatus; C. stellatus; C. crassilabratus; C. morungavensis; C. microvacuolatus; Reticulatisporites asperidictyus; Leiotriletes virkkii; Punctatisporites gretensis; Cyclogranisporites parvigranulosus; Anapiculatisporites argentinensis; Apiculatisporis variornatus; Raistrickia pinguins; $R$. paganciana; $R$. rotunda; Foveosporites hortonensis; Cannanoropollis janakii; $C$. triangularis; Plicatipollenites malabarensis; $P$. densus; $P$. gondwanensis; Potonieisporites novicus; $P$. neglectus; $P$. barrelis; $P$. brasiliensis; $P$. magnus; 


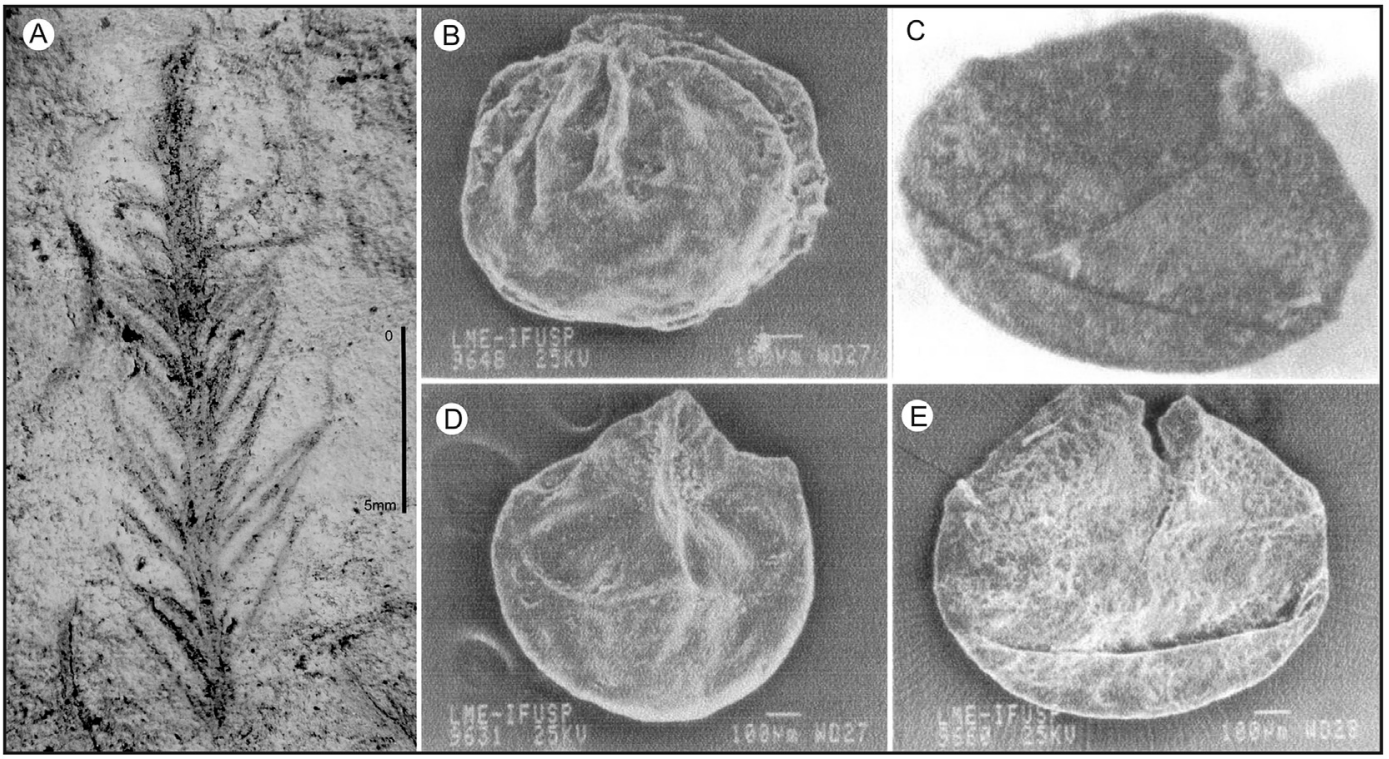

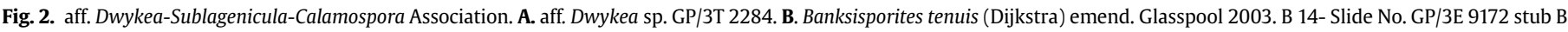

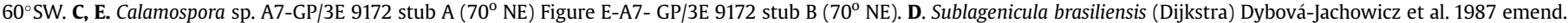
Glasspool 2003 A1- GP/3E 9172 stub A 90 SE.

Divarisaccus stringoplicatus; Caheniasaccites flavatus; Limitisporites rectus; L. hexagonalis; Protohaploxypinus amplus; cf. Hamiapollenites sp. and Botryococcus braunii. Based on the presence of Anapiculatisporites argentinensis, Cristatisporites inordinatus and Psomospora detecta, these strata were characterized into the Ahrensisporites cristatus Interval Zone (AcZ) of Souza (2000, 2006), corresponding to the lower portion of the Itararé Group, corresponding to a Westphalian (= Bashkirian-Moscovian) age.

\subsubsection{Paleoecology}

This macrofloristic association suggests the existence of a vegetation, probable tundra-like, consisting of bryophytes and lycophytes, in association with sphenophytes, filicophytes and gymnosperms (possible Pteridospermales and/or Coniferales) as indicated by palynomorphs. This phytofossiliferous association allows recognizing a para-autochthony because it aggregates elements of marine coastal environments like tidal plains to others of riparian environments or of fluvial flood plains and to the high continental areas. The autochthony is represented by thalli of bryophytes, which could thrive on rock coast and lycophyte megaspore tetrads on the tidal plains. The allochthonous elements are represented by spores of sphenophytes and filicophytes which could have thrived on the flood plains and the pollen grains of pteridosperms or conifers in mesophytic areas.

The depositional environment could be shallow coastal waters and related to delta evidenced by the huge quantity of megaspores, the equal proportion of pollen grains and spore tetrads and by the preservation of delicate folious caulids of bryophytes, which suggest a very short transport (Tyson, 1995). The massive mudstone and fine to very fine granodecrescent sandstones were interpreted by Souza Filho (1986) as distal subaqueous fan facies. But the presence of bioturbation and cross stratification or plano-parallel lamination associated with delicate macrofossils could suggest a marine coastal environment like tidal plains in a shallow epicontinental sea with variable rate of sediment influx (P.R. dos Santos, personal communications; Amaral and Ricardi-Branco, 2004). This coastal vegetation, tundra-like suggests the beginning of a deglaciation context of an interglacial phase, with glaciers recession, i.e., of proglacial landscape. This situation is very unusual in the paleontological record of the world.

\subsubsection{General considerations of the aff. Dwykea-Sublagenicula- Calamospora Association}

Based on its stratigraphical position, i.e., near the lower contact of the Itararé Group with the crystalline basement, in the Campinas Municipality (SP) area and also because it belongs to the Ahrensisporites cristatus Interval Zone (AcZ) of Souza (2006) and Souza et al. (2006), this macrofloristic association is considered the oldest among those described herein (Table 3).The specific diversity of palynomorphs preserved in shallow marine rhythmic sediments with ichnofossils, in a general context of the Permo-Carboniferous glaciation situated under diamictites, indicates the existence of vegetation near the coast, tolerant to rigorous climates. This vegetation could occupy different habitats such as brackish, occupied by lycophytes (made evident by the short transport of megaspore tetrads), coastal rocky areas covered by bryophytes (also of small transport as demonstrated by the delicate preservation of their foliar sporophyte axis), flood plains of continental fresh water where sphenophytes and filicophytes thrived (revealed by the presence of Calamospora, Punctatisporites and Raistrickia) and inland higher and drier environments covered by pteridospermales and coniferales (revealed by the presence of pollen grains and unidentifiable branches or stems with 1 or $2 \mathrm{~cm}$ of diameters).The vegetation could be similar to tundra (present day biome of Alaska and north Canada or south extremity of Argentina and Chile), perhaps associated with a marine transgression at the end of a glacial phase, inferred in the area by the occurrence of the Hortolândia marine fauna. The reconstruction of the landscape is given in Fig. 3.

\subsection{Eusphenopteris-Nothorhacopteris-Botrychiopsis Association (ENB As)}

\subsubsection{Type locality}

This association has as taphoflora type that occurs in the Santa Marta Farm, in the Itapeva Municipality, São Paulo State (Fig. 4). 


\subsubsection{Occurrences}

Santa Marta Farm (Itapeva Municipality, São Paulo State), Paineira I Farm and Paineira II Farm and Enxovia stream (Buri Municipality, São Paulo State).

\subsubsection{Stratigraphic position}

The area of Buri and Itapeva in the southwestern part of the state of São Paulo is situated at the north of the Ponta Grossa Arch, near the Guapiara Lineament. The sediments of the Itararé Group are predominant in this area, directly on the crystalline basement in the southern part of the area or on Devonian rocks in other areas and are covered by the sediments of the Tatuí Formation in the north. According to Cabral and Motta (1985), tectonically, the area shows a staggered faulting system like "horst and graben", in two preferred directions NW-SE and NE-SW with displacements ranging up to more than two hundred meters (Fig. 4). Here, the Itararé Group is characterized by the presence of a large variety of lithologies dominated by very fine to conglomeratic sandstones but also with diamictites, rhythmites, siltstones, shales, and massive claystones including coal layers.

According to Cabral and Motta (1985), there are four lithofacies units recognized within the Itararé deposits in this region viz. Unit $\boldsymbol{A}$ - Basal pelitic rocks with some sandstones interpreted as prodelta and deltaic front facies; Unit B-Immediately above them are fine to medium sandstones along with conglomerates and siltstone lens with plant remains and coal layers with a thickness of $50 \mathrm{~m}-100 \mathrm{~m}$, interpreted as deposits of deltaic plain environment; Unit $\boldsymbol{C}$ composed of siltstones and fine sandstones interlaminated and intensely bioturbated. Micro cross stratification, wavy lamination and flaser type suggest a deltaic front environment to a shallow platform environment in a transgressive phase on the deltaic plain sediments of the unit B with accumulation of interglacial coal. Unit $\boldsymbol{D}$ - comprises predominantly sandstones and diamictites. There is a basal lithological assemblage of sandstones of diverse granulometry, sometimes arkosic with conglomeratic levels and coal fragments and an upper lithologic assemblage comprising sandstones, diamictites and pelitic beds. This unit represents a relation of continental facies truncating marine sequences showing a coastal marine depositional environment of the deltaic fan type. The sedimentation in this area shows a cyclic character indicating sedimentation by pulses caused by advances and retractions of glaciers (Silva, 19944). Some authors such as Ciantelli Jr. et al. (1983), Cabral and Motta (1985) and Silva (1994) have considered this area in an upper-middle stratigraphic position of the Itararé Group (Fig. 4).

Lithostratigraphically, this association was included in the "Unit B" of Cabral and Motta (1985), in a horst outcropping within a matrix of fine clastic lithologies associated with coal, under the fine sediments of the "Unit C", which are overlapped by diamictites of the "Unit D" (Cabral and Motta, 1985).This association is also situated at the middle lower part of the Itararé Group, based on its palynological content given by Zampirolli et al. (2000).

\subsubsection{Macrofloristic taxonomic contents}

The Santa Marta Farm taphoflora had its components preliminarily identified by Millan et al. (1982) and later in a series of papers published by Millan (1987b, 1989a, 1991a, 1991b, 1993, 1995a, 1995b). The resultant macrofloristic taxa list was modified by revisions done by Zampirolli et al. (1999); Zampirolli (2001); Zampirolli and Bernardes-de-Oliveira (2001) resulting in the following taphofloristic composition: Paracalamites australis; P. montemorensis; P. levis; Paracalamites sp.; Sphenophyllum cf. S. churulianum; S. cf. S.rhodesii; S. sp; cf. Koretrophyllites sp.; Botrychiopsis plantiana; cf. Eusphenopteris sp.; Nothorhacopteris cf. $N$. argentinica; Noeggerathiopsis sp.; Cordaicarpus zeilleri and Samaropsis itapevensis. The most abundant forms are: cf. Eusphenopteris (the only locality in the Itararé Group where this genus was hitherto recognized), Botrychiopsis plantiana, Paracalamites levis, $P$. australis, P. montemorensis, Sphenophyllum rhodesii and Cordaicarpus zeilleri. In this level, Botrychiopsis, Sphenophyllum and Paracalamites appeared for the first time in the Paraná Basin.

The macroflora of Buri has only one element recognized hitherto, Nothorhacopteris sp. It was registered by Perinotto and Rösler (1987) from a subsurface material. The macrofloral composition of this association is given in Table 4 and illustrated in Fig. 5.

\subsubsection{Palynological content and age}

The microflora of Santa Marta Farm comprises of Potonieisporites brasiliensis, P. congoensis, Caheniasaccites flavatus, Divarisaccus stringoplicatus, Plicatipollenites malabarensis, P. densus,

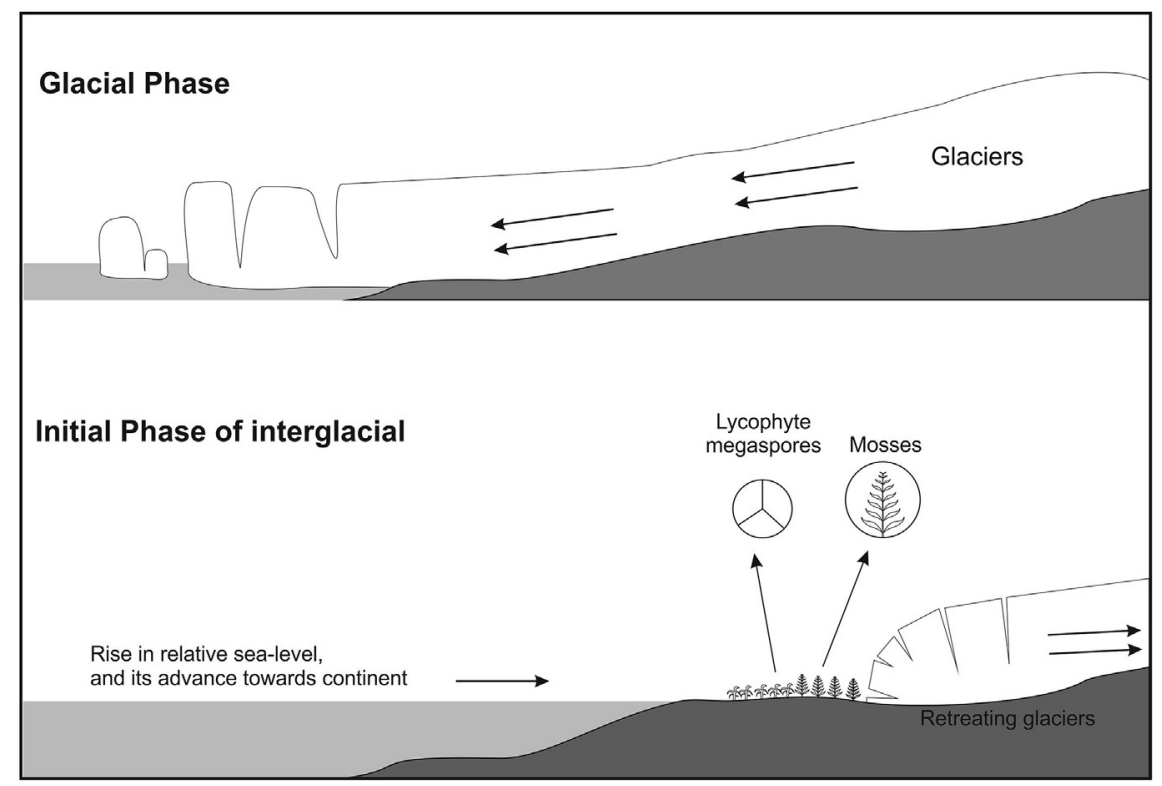

Fig. 3. Reconstruction of the landscape in Campinas during Late Bashkirian to Moscovian, as proposed by R.Rohn (personal communication) with modifications. 


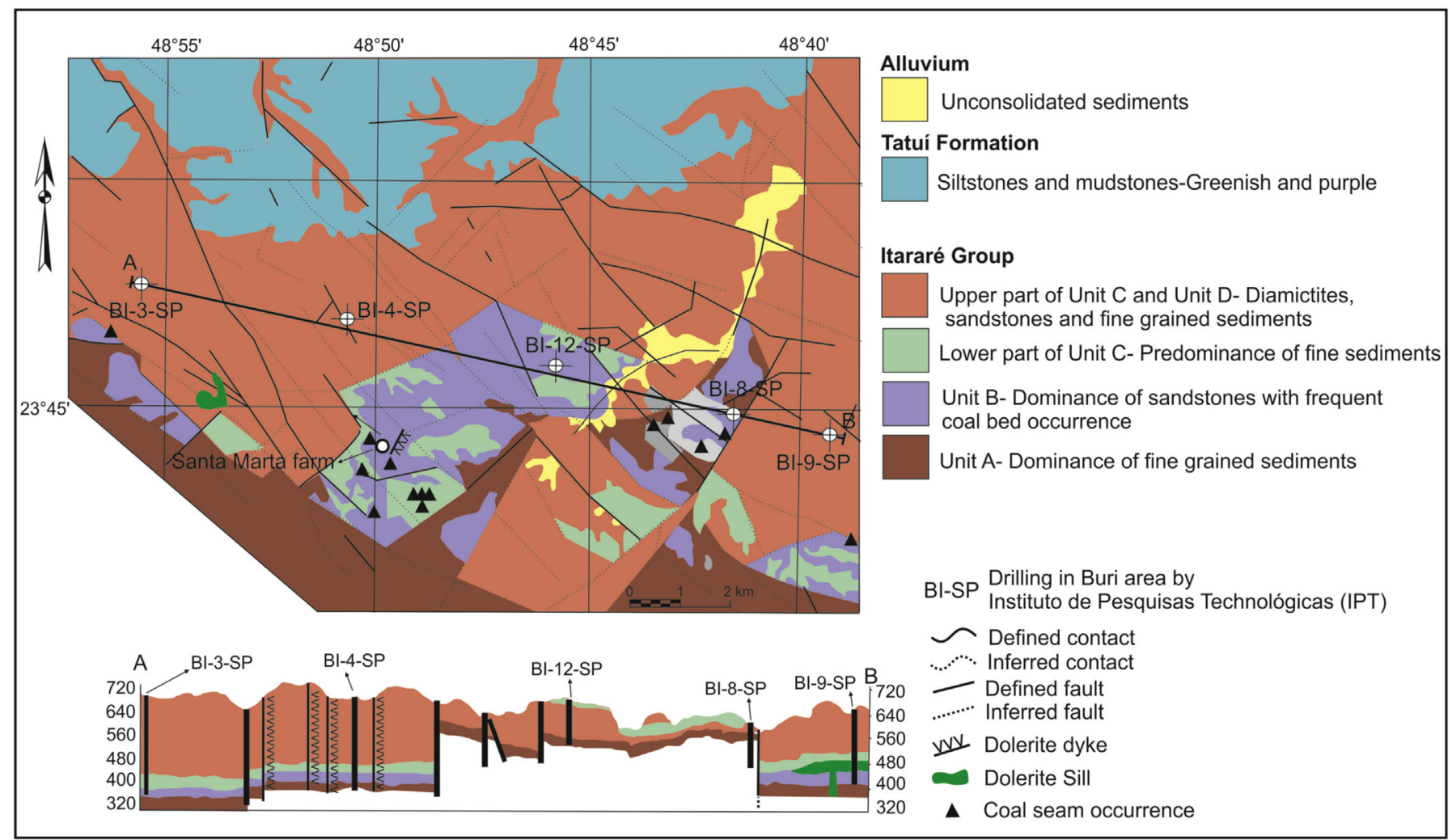

Fig. 4. Map and geological section of Buri and Itapeva area, after Cabral and Motta (1985) (modified from Zampirolli, 2001).

Cannanoropollis janaki (Zampirolli et al., 2000).The Buri palynological composition shown by Souza et al. (1993) was revised by Souza (2003) resulting in the following taxa list: Ahrensisporites sp., Anapiculatisporites argentinensis, Apiculiretusispora tuberculata, Brevitriletes levis, Cingulizonates landesii, Convolutispora muriornata, C. ordonenzii, Cristatisporites connexus, C. inordinatus, $C$. spinosus, $C$. menendezii, C. sp. 1 and 2, Densosporites spp., Dictyophyllidites sp. 1 and 2, Foveosporites hortonensis, Laevigatosporites sp., Lundbladispora braziliensis, L. riobonitensis, Murospora bicingulata, Psomospora detecta, Punctatisporites foveolatus, P. gretensis, Raistrickia paganciana, $R$. pinguis, $R$. rotunda, $R$. sp. 2, Secarisporites irregulares $S$. sp., Stenozonotriletes clarus, Vallatisporites ciliaris, V. spinosus, V. vallatus, Caheniasaccites flavatus, Cannanoropollis densus, C. sp., Crucisaccites latisulcatus, Divarisaccus stringoplicatus, Plicatipollenites malabarensis, P. trigonalis, Potonieisporites brasiliensis, P. magnus,
Protohaploxypinus sp., Tetraporina horologia, Deusilites tenuistriatus, Portalites gondwanensis and Mychrystridium sp. This composition was ascribed to the Ahrensisporites cristatus Interval Zone (AcZ) of Souza (2006), attributed to the Late Bashkirian to Moscovian age. Correlation between the Buri coal and the Malanzán Formation of the Paganzo Basin, Argentina was also proposed. Souza et al. (1993) detected the presence of an Acritarch like Michrystridium sp. typical of coastal shallow marine waters in the palynocomposition of the Buri coals. The predominant palynological components suggest a vegetation characteristic of wet lowlands (lycophytes, sphenophytes and filicophytes) indicating the deposition of sediments in a deltaic plain.

\subsubsection{Paleoecology}

The sedimentary environment of the "B Unit" of Cabral and

Table 4

Macrofloral composition of Eusphenopteris-Nothorhacopteris-Botrychiopsis Association.

\begin{tabular}{|c|c|c|}
\hline Taphofloral group & Millan et al., 1982; Millan (1987a,b-1995a,b) & Zampirolli (2001) \\
\hline \multirow[t]{8}{*}{ Sphenopsids } & Paracalamites australis & Paracalamites australis \\
\hline & Sphenophyllum cf. S. churulianum & Paracalamites montemorensis \\
\hline & Sphenophyllum sp. & Paracalamites levis \\
\hline & & Paracalamites sp. \\
\hline & & Sphenophyllum cf. S. Churulianum \\
\hline & & Sphenophyllum cf. S.rhodesii \\
\hline & & Sphenophyllum sp. \\
\hline & & cf. Koretrophyllites sp. \\
\hline \multirow[t]{4}{*}{ Pteridophylls/Progymnospermopsids } & Botrychiopsis plantiana & Botrychiopsis plantiana \\
\hline & Nothorhacopteris argentinica & cf. Eusphenopteris sp. \\
\hline & & Nothorhacopteris cf. N. argentinica \\
\hline & & Aphlebia of Nothorhacopteris cf. $N$. argentinica \\
\hline \multirow{3}{*}{ Gymnospermopsids } & Cordaites cf. C. Spathulata & Noeggerathiopsis sp. \\
\hline & Cordaicarpus zeilleri & Cordaicarpus zeilleri \\
\hline & Samaropsis itapevensis & Samaropsis itapevensis \\
\hline
\end{tabular}




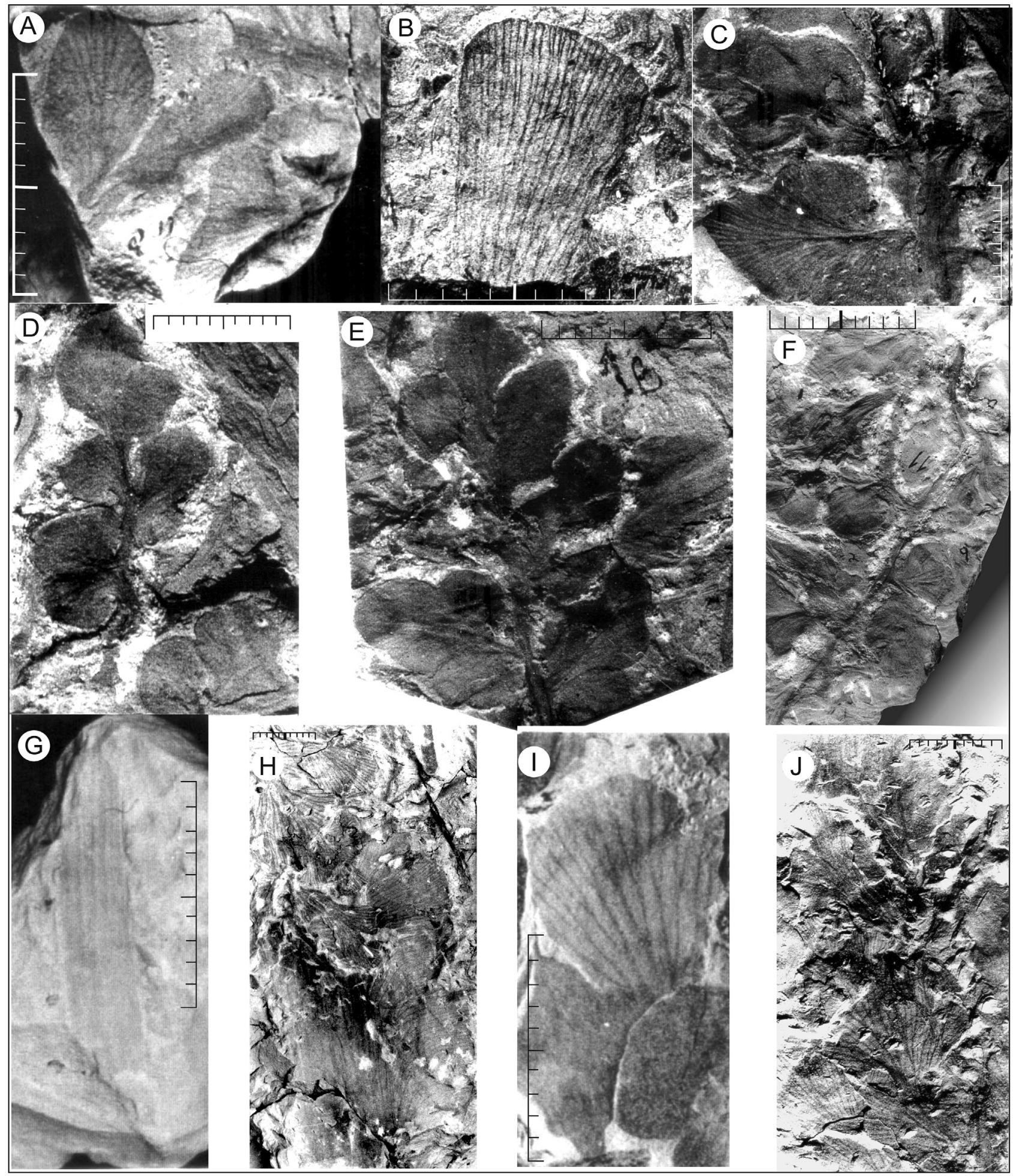

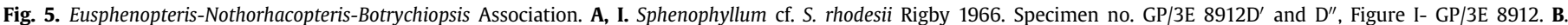

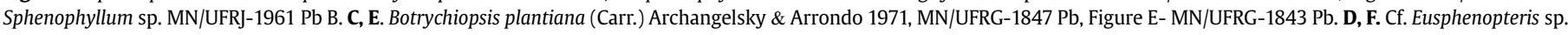

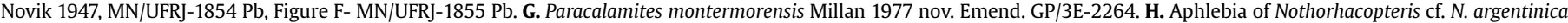
Archangelsky 1983. GP/3E-892 8B. J. Nothorhacopteris cf. N. argentinica Archangelsky 1983, GP/3E8928 A.

Motta (1985) is interpreted as a deltaic plain, with a large accumulation of woody material and other macrophytofossils. The evidences for this environment are indicated by lithologies such as medium to fine sandstones, with conglomerate lens, siltstones and coal beds with sedimentary structures such as cross-stratifications and bioturbation by roots. The accumulation of terrestrial organic matter giving rise to the coal beds and foliar stem and seed impressions deposited over each other with few clastic material among them is suggestive of plants deposited "in situ" or with short transport in a deltaic plain context. It was in a reducing, 
undisturbed, aquatic environment of interdistributary plains, where the hygrophyll, hygro-mesophyll and putative mesophyll plants of short transport were accumulated.

The hydro-hygrophyll coal precursor communities are represented by the sphenophytes (Sphenophyllum, Koretrophyllites, etc). The communities with hygro-mesophylls to mesophylls edaphic exigencies are represented by pteridosperms or progymnosperms (Nothorhacopteris, Botrychiopsis and Eusphenopteris) (Archangelsky, 1983; Cúneo, 1986; Archangelsky and Cúneo, 1991).The mesoxerophytic communities were formed by pteridospermales, cordaitales and probable conifers whose presence is denoted only by pollen grains (like Plicatipollenites, Potonieisporites, Caheniasaccites and Limitisporites). These plants would have probably existed far away from this depositional site on higher regions and their pollen grains would have been transported to the site by wind or run-off. The abundant vegetation would suggest that an interglacial phase of warmer climate was predominant in this area.

\subsubsection{General assessment of the Eusphenopteris-Nothorhacopteris- Botrychiopsis Association}

The ENB Association that occurs in the type-locality, Santa Marta Farm in Itapeva (SP), and also in Paineiras I and II Farms and Enxovia stream in Buri (SP), comprises of herbaceous forms like lianes or hydro-hygrophilous type of lowlands, partially or completely flooded with several species of Sphenophyllum, generally associated with wet cold temperate climates; riparian to lake forms such as Koretrophyllites, arbustive forms of principal axes with verticillate stems which permitted certain stability on soft substrata of stagnant waters related to marginal lacustrine areas and deltaic interdistributary basins; arbustive pteridosperm communities of Botrychiopsis that could grow as dwarfish forms in proglacial "tundra" environments in association with cordaitalean forms (Noeggerathiopsis) of hygro-mesophilous to mesoxerophilous edaphic exigencies. These elements suggest that they thrived in areas where the glaciers retreated, in a mild warm climate and marine transgressive phase with wet coastal conditions favoring peat bog formation. These plants, in general, of short appearance and low diversification are evidences of cooler climatic conditions, with long and few mild winters. A schematic figure of this type of landscape is given in Fig. 6.

The components of this association favor its correlation with the NBG Phytozone of Argentina and with the Nothorhacopteris flora of Australia, giving it a Bashkirian to Kasimovian age (Azcuy et al., 2007). Based on the radiometric dating, Césari et al. (2011) established recently an older interval for NBG Phytozone in Argentina, considering it as spanning from Serpukhovian to Bashkirian.

\subsection{Paranocladus-Ginkgophyllum-Brasilodendron Association (PGB As)}

\subsubsection{Type locality}

Volpe Ranch (previously named Mine Ranch), in the Monte Mor Municipality (State of São Paulo), Fig. 1.

\subsubsection{Occurrence}

Only in Volpe Ranch, Monte Mor Municipality (SP).

\subsubsection{Stratigraphic position}

Lithostratigraphic position of this taphoflora in the Itararé Group is very difficult to be precised. In the Volpe Ranch outcrop, it is possible to observe that the clayey siltstones, shales and claystones associated with the coal beds are under a tillite. They are considered belonging to the Unit IV of Souza Filho (1986: 32-35, Fig. 7) because the lithologies of this unit also contain several bodies of conglomeratic sandstones and medium-fine mudstones including coal or carbonaceous beds. These lithologies occur within different stratigraphic levels of the Unit III which is considered by Souza Filho (1986) as lower middle part in this outcropping area of the Itararé Group (Fig. 7). Based on its macro and microfloristic contents, Rocha-Campos and Rosler (1978) and Souza et al. (1997) inserted Monte Mor occurrence in the middle-lower part of the Itararé Group.

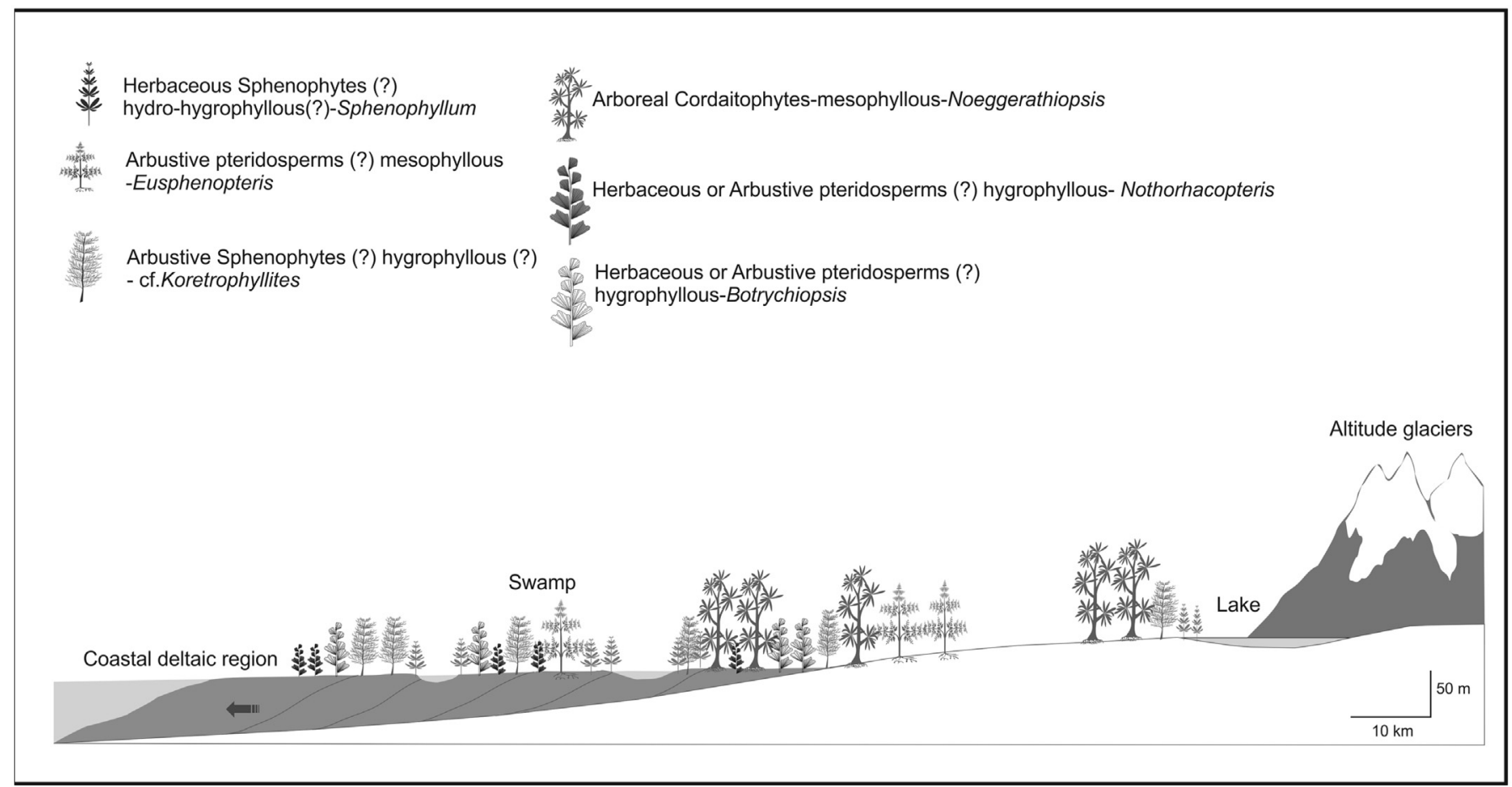

Fig. 6. Reconstruction of the landscape in Itapeva and Buri area during Late Bashkirian to Moscovian, as proposed by R. Rohn (personal communication) with modifications. 


\subsubsection{Macrofloristic taxonomic contents}

The study of the Volpe Ranch macroflora was developed firstly by Millan (1972) followed by many of his successive publications (Millan, 1974, 1975, 1977a, 1979, 1980a, 1980b, 1981a, 1981b, 1985). This macroflora was also the subject of revision in the Master Degree Dissertation of Mune (2005) and other studies by Mune et al. (2012a,b).

This taphoflora is mostly rich in lycophytes (Brasilodendron and Bumbudendron) and conifers (Paranocladus and Buriadia) with some subordinate elements of sphenophytes (Paracalamites spp and Koretrophyllites), pteridospermales (Botrychiopsis and Nothorhacopteris), Ginkgoales (Ginkgophyllum), occurring in clayey siltstones and shales associated with coal beds. The revision of this macroflora by Mune and Bernardes-de-Oliveira et al. (2007a) furnished the following composition list (Table 5).

The dominant forms of this association are: Paranocladus, cf. Paranospermum, Ginkgophyllum, Brasilodendron, and Paracamalites.
Common forms include: Bumbudendron, Noeggerathiopsis, Buriadia, Samaropsis and Cordaicarpus. Other forms present in this association are: Nothorhacopteris, Botrychiopsis cf. B. plantiana, cf. Cyclodendron sp. and Leptophloeum cf. L. sanctae-helenae. The conifers Buriadia and Paranocladus dusenii and its respective seed Paranospermum have their first biostratigraphic appearance in Paraná Basin in the Monte Mor macroflora. The macrofloral composition of this association is given in Fig. 8.

\subsubsection{Palynological content and age}

The palynological contents of the Monte Mor sediments were initially identified by Daemon (1974), who verified the occurrence of laevigate, apiculate and zonate spores and monosaccate and striate pollen grains along with Tasmanites sp? and unidentified hystrichospherid, considered reworked. He attributed the Monte Mor coal to the $\mathrm{H}_{1} / \mathrm{H}_{2}$ subintervals in palynostratigraphic position of Sakmarian age in the Daemon and Quadros (1970) scheme. Later

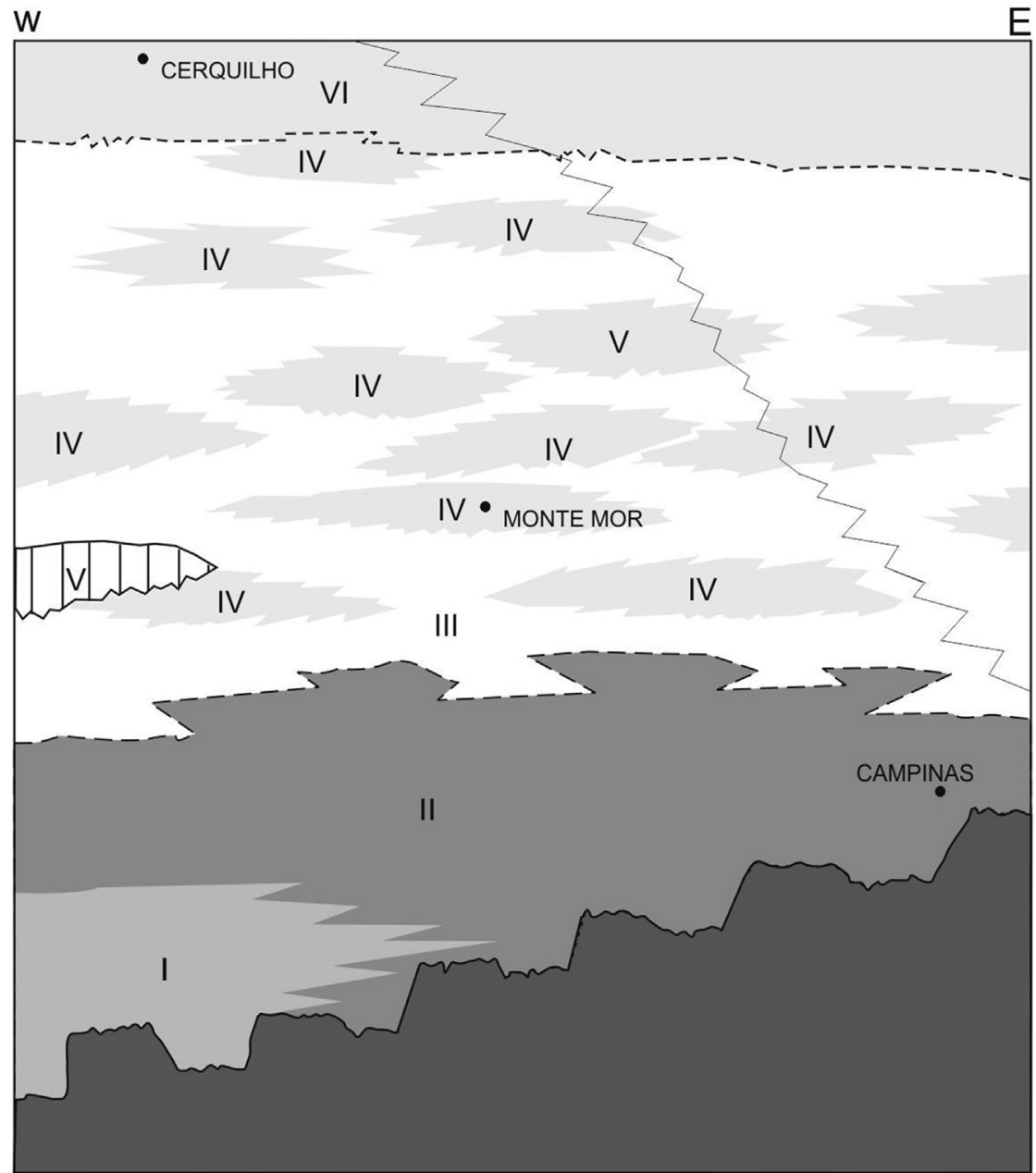

\section{Crystalline Basement}

1 Sandstone

II Mudstone

Contact not known m Erosive contact
E

III Mudstones and Diamicties

IV Sandstone

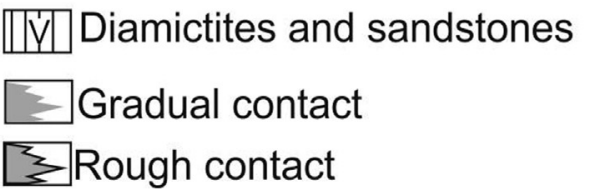

Fig. 7. Lithostratigraphical units of itararé group in monte mor (modified from Souza Filho, 1986). 
Table 5

List of megafossil components of the Volpe Ranch (Monte Mor, SP), macroflora $\left({ }^{* * *}=\right.$ Not identified before).

\begin{tabular}{|c|c|c|}
\hline Milan 1972 to 1987 & Actual list & No. Of specimens \\
\hline Lepidodendron pedroanum & Leptophloeum cf. L. sanctae-helenae & 1 \\
\hline Lycopodiopsis pedroanus (parts)/B. pedroanum (parts) & Brasilodendron pedroanum & 7 \\
\hline *** & aff. Brasilodendron sp. & 1 \\
\hline Lycopodiopsis pedroanus (parts)/B.pedroanum (parts) & Bumbudendron $\mathrm{cf}$. B. paganzianum & 3 \\
\hline Lycopodiopsis sp. A; Lycopodiopsis pedroanus (parts)/B.pedroanum (parts) & Bumbudendron millanii & 3 \\
\hline Lycopodiopsis derbyi & cf. Cyclodendron sp. & 3 \\
\hline Sphenophyllum sp. A (parts) & Trizygia sp. & 1 \\
\hline Sphenophyllum sp. A (parts) & Indeterminate Sphenophyllales & 4 \\
\hline Paracalamites cf. P. levis (parts) & Koretrophyllites sp. & 4 \\
\hline Paracalamites australis (parts) & Paracalamites australis & 8 \\
\hline Paracalamites cf. P. levis (parts). & Paracalmites levis & 10 \\
\hline Paracalamites montemorensis (parts) & Paracalamites montemorensis & 12 \\
\hline Paracalamites australis (parts) & Paracalamites sp. & 1 \\
\hline Nothorhacopteris cf. N.ovata & cf. Nothorhacopteris sp. A & 3 \\
\hline Nothorhacopteris cf. N.chubutiana & cf. Nothorhacopteris sp. B & 2 \\
\hline Botrychiopsis cf. B.Plantiana; Adiantes sp. & Botrychiopsis cf. B. plantiana & 4 \\
\hline ? Botrychiopsis cf. Weissiana & cf. Botrychiopsis sp. & 2 \\
\hline cf. Ginkgophyllum sp. A & Ginkgophyllum cf. G. diazzi & 10 \\
\hline$* * *$ & Ginkgophyllum cf. G. kidsonii & 1 \\
\hline$* * *$ & (?) Ginkgophyllum spatulifolia & 1 \\
\hline Noeggerathiopsis hislopii & Noeggerathiopsis cf. N. hislopii & 6 \\
\hline Paranocladus? fallax & Paranocladus dusenii & 14 \\
\hline Buriadia heterophylla & Buriadia aff. B. heterophylla & 5 \\
\hline Cordaicarpus barbosanus & Cordaicarpus barbosanus & 1 \\
\hline$* * *$ & Cordaicarpus cesarii & 1 \\
\hline$* * *$ & Cordaicarpus sp. & 3 \\
\hline Cordaicarpus nitens (parts) & Paranospermum cambuiense & 34 \\
\hline Cordaicarpus nitens (parts) & Paranospermum millanianum & 8 \\
\hline$* * *$ & Samoropsis barcellosa & 1 \\
\hline$* * *$ & Samoropsis cf. S. cuerdai & 1 \\
\hline Samaropsis seixasi & Samoropsis aff. S. seixasii & 2 \\
\hline
\end{tabular}

the microfloristic studies of the Monte Mor sediments were carried out by Souza et al. (1997), Souza (2000), Mune (2005); Mune and Bernardes-de-Oliveira, (2007a) and Jha et al. (2012).

Souza et al. (1997) analyzed the Monte Mor palynological assemblage and found it richer in striate pollen grains such as Protohaploxypinus in comparison with Buri palynological assemblage (Souza et al., 1993). They concluded that this difference could be attributed to a paleoecological control or an older age of Buri Coal. Souza (2000) preferred to consider as more probable the possibility of this difference in palynocomposition as a result of distinct paleoecological sources because Araçoiaba da Serra and Monte Mor not only presented a greater diversification of striate pollen grains than Buri but also were associated with spores (Ahrensisporites cristatus, Cristatisporites spp, Reticulatisporites muricatus) and monossacate pollen grains (Florinites occultus, Caheniasaccites flavatus, Cannanoropollis janakii, C. perfectus, Limitisporites rectus, Plicatipollenites malabarensis, Potonieisporites barrelis, $P$. magnus, $P$. novicus) which meant a Westphalian age, similar to Buri. Therefore, Souza $(2000,2006)$ and Azcuy et al. (2007) considered Monte Mor, Araçoiaba da Serra, Buri and Itapeva as belonging to the same Ahrensisporites cristatus Interval Zone of Westphalian age (=Late Bashkirian to Moscovian age).

However, Mune (2005) and Jha et al. (2012) have observed Scheuringipollenites maximus in the palynological assemblage of Monte Mor and have attributed to it a Kasimovian to Gzhelian age, i.e., to the Crucisaccites monoletus Interval Zone (CmZ) of Souza (2006).

This work which is based on macrofossil associations agrees with this point of view considering that it corresponds to the first appearance of conifers (Paranocladus, Buriadia and seeds such as Paranospermum) in Paraná Basin, and the greater number of species in common with Krauselcladus-Astherotheca Phytozone of Argentina. Therefore, both micro and macrofossils are indicative of better correlation with Krauselcladus-Astherotheca than with NBG Phytozone.

It must be noted that the pollen grains of gymnosperms are very anemophillous, mostly, those of conifers. This factor could lead to a palynological homogenization mainly among areas very close to the coast with marine and continental breeze, as was this entire region. But this homogenization did not take place. New unpublished data was obtained from Monte Mor coal levels in these last years, increasing the palynological taxa list including certain species of plant spores (such as Convolutispora ordonenzii, Psomospora detecta) and fungi (Portalites gondwanensis).

The palynological differences between the compositions of Itapeva/Buri and Araçoiaba da Serra/Monte Mor associations can be interpreted by the following reasons: (i). They are stratigraphical levels chronologically distinct, better than paleoecologically controlled; (ii). These associations are related to the same palynozone (ZAc), but not necessarily to the same correlatable stratigraphical horizons, with some chronological and paleoecological differences between them; (iii). The possibility of C.monoletus has an extensive range than previously known must be checked and then adjustments in palynozones are needed.

\subsubsection{Paleoecology}

The lobe deltaic facies of Monte Mor would be included genetically in a deltaic system, into a continental platform shallow sea where pro-gradational and retro-gradational events are recorded. The basal sequence documents the initial prodelta domain (siltstones intercalated with fine sandstones), which passes into the proximal deltaic front facies (very fine sandstones), thereafter to a deltaic plain or floodplain (massive conglomerates, tabular and fluted cross-bedding sandstones, purplish mudstones and mudstones with coal, plan parallel sandstone and with ripple marks), followed on the top by a thin facies, such as sandstones with ripple 

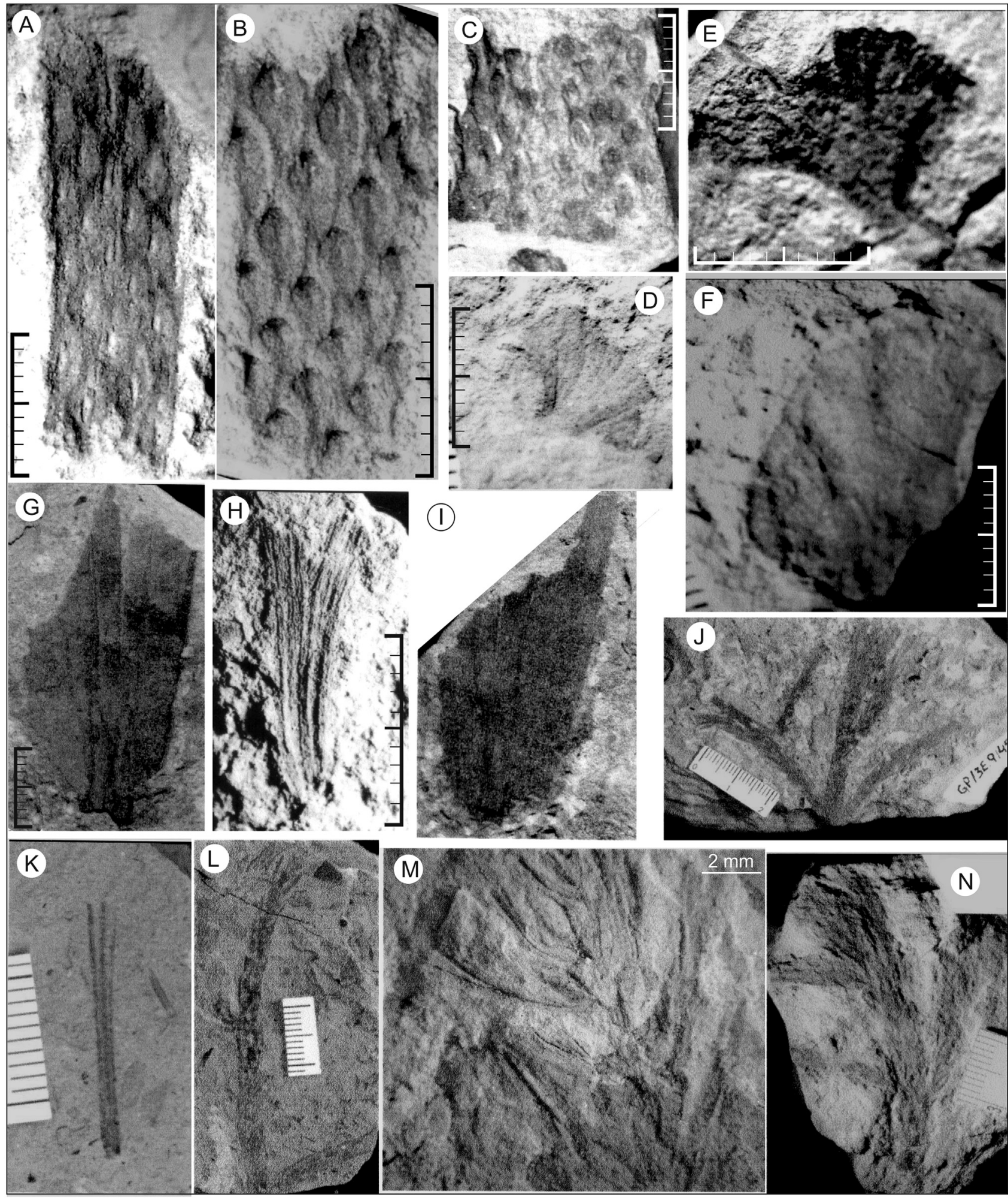

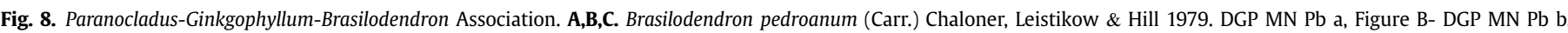

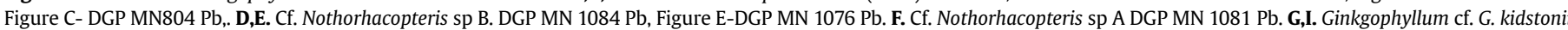

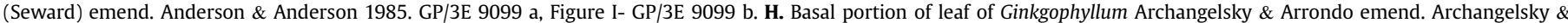

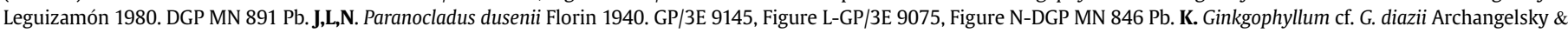

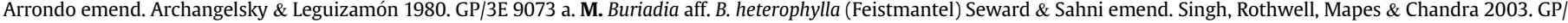
3E 9147 a.

marks, cross-bedding of high angle, siltstones and shales (Souza Filho, 1986; Souza et al., 1997). The deposition site is a sequence of prodelta, deltaic front, beach, flood plains and dune environments before the initiation of the new glacial cycle. In the deltaic 
plain, fluvial channel deposits aggregated the mudstones with coal, muddy sandstones and grey sandstones, rich in organic matter and coal with massive structures of flaser and lens, silts with plant remains and freshwater fossils. The proximal deltaic front or tidal plain and delta plain fluvial channel deposits characterize the outcrop of Volpe Ranch finalizing in an ablation flux till supraglacial facies and clasts pavements and loading tillites, at the top (Souza Filho, 1986).

The Monte Mor taphoflora, deposited in the delta plain or floodplain, records the development of hydro-hygrophyll vegetation in peat bogs evidenced mostly by the presence of lycophytes such as Bumbudendron, Brasilodendron, Leptophloeum, Cyclodendron and sphenophytes such as Paracalamites and Koretrophyllites. This association presents hydro-hygrophyllic forms typical of total or partially flooded riparian zones. These forms would be inhabitants of quiet to stagnant water borders of plain rivers or interdistributary areas of deltaic basins. These areas were dominated, probably, by well diversified lycophytes which accumulated in large quantities in some areas, leading to the generation of coal peatery.

This community was represented by hygrophyll and mesophyll elements of the progymnosperms and pteridosperms like Nothorhacopteris, Botrychiopsis, Ginkgoales like Ginkgophyllum and Cordaitales like Noeggerathiopsis. The predominance of conifers (Paranocladus, Buriadia and seeds such as Paranospermum) associated to Ginkgoales (Ginkgophyllum), i.e., of allochtonous elements in upper beds (20-40 cm above) constituted by thicker clasts (silty sands to arkosic thick sandstones), with paucity or absence of filicophytes and progymnospermic or pteridospermic elements (Botrychiopsis, Nothorhacopteris) lead to the conclusion of dominance of a montane elements. This indicates that the Coniferales (such as Paranocladus and Buriadia) were proliferating in a more xerophytic montane to sub-montane environment.

The vegetation is suggestive of a cool temperate climatic biome of an interglacial phase. The interglacial Monte Mor flora flourished under a latitude of $60^{\circ} \mathrm{S}$, as suggested by the paleogeographic maps (Scotese, 2000) which confirmed this condition (Fig. 9).

The milder climate established with the retraction of the glaciers and the probable proximity of marine environment from west, allowed the development of relatively abundant vegetation, enabling the formation of coal beds, although not very thick. The presence of Botryococcus and conchostraceous carapaces which are characteristic of fresh water are suggestive of continental environment of deposition. A reconstruction of this scenario is shown in Fig. 10.

This scenario culminated with the arrival of another new glaciation documented 3 or $4 \mathrm{~m}$ above by Elias Fausto diamictites/ tillite.

\subsubsection{General considerations of the Paranocladus-Ginkgophyllum- Brasilodendron Association}

Despite the bad preservation of the specimens of this association studied by Millan (1972, 1974, 1975, 1977a, 1979, 1980b, 1981a, 1981b, 1985) and also of the recently collected specimens, the presence of many identified taxa registered were confirmed and new ones were identified by Mune (2005) and Mune and Bernardes-de-Oliveira (2007b). Analysing the taxonomy of the component elements of Monte Mor association in Volpe Ranch outcrop, it is possible to assert that the strata underlying the coal (foot-wall) contains abundant lycophytes: Brasilodendron (the more frequent), Bumbudendron, Leptophloeum and cf. Cyclodendron. In the level over the coal (hanging-wall or cap-rock), were preserved sphenophytes (rare Koretrophyllites and abundant Paracalamites) and some representatives of progymnospermales/pteridospermales (Nothorhacopteris and Botrychiopsis but differ from Itapeva taphoflora by an absence of Eusphenopteris). Some Ginkgoales (Ginkgophyllum) and some Cordaitales (Noeggerathiopsis) are common among the abundant conifers (Paranocladus, Paranospermum and Buriadia).

Iannuzzi (2001) considered that the macroflora of Monte Mor presented characteristic elements of three Argentinean phytozones: NBG (Nothorhacopteris-Botrychiopsis-Ginkgophyllum); Interval and Gangamopteris (Archangelsky and Cúneo, 1984). Above the NBG phytozone, Azcuy et al. (2007, Fig. 3.1, 3.2, 3.3). recognized, in the Uspallata-Iglesia, Paganzo and Tepuel-Genoa basins, another Late Carboniferous phytozone formally proposed by Carrizo and Azcuy (2006) for Paganzo and Rio Blanco basins as KrauselcladusAstherotheca Phytozone for the previously named Interval phytozone. The characteristic species of this phytozone are Botrychiopsis plantiana, B. weissiana, Brasilodendron sp., Bumbudendron nitidum, Cordaicarpus cesariae, Eusphenopteris sanjuanina, Ginkgophyllum diazii, Nothorhacopteris argentinica, Paracalamites australis, Paracalamites levis, Paranocladus? fallax, Samaropsis cuerdae which are common or with affinities with the present PGB Association.

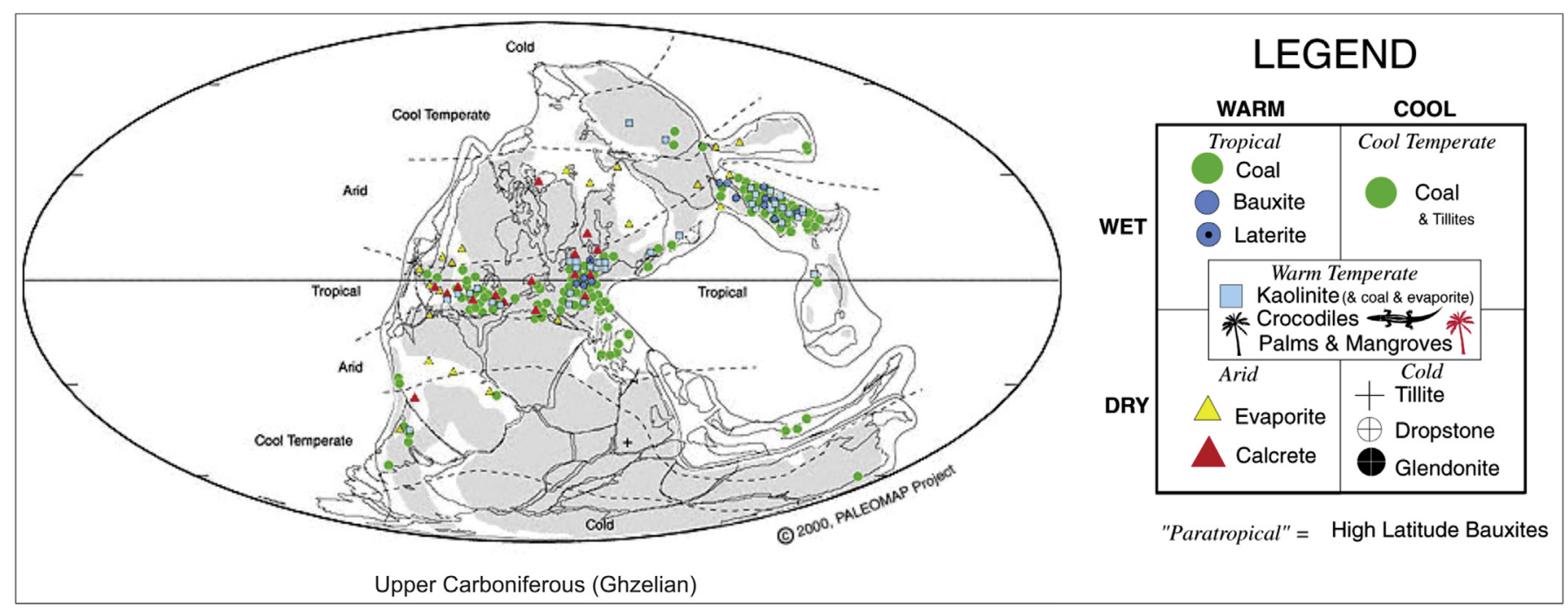

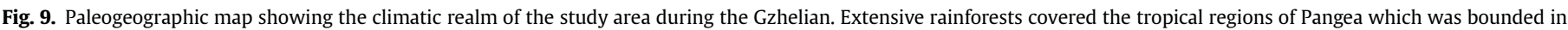
the north and south by deserts. An ice cap covered the South Pole. Source: http://www.scotese.com/gzelclim.html. 


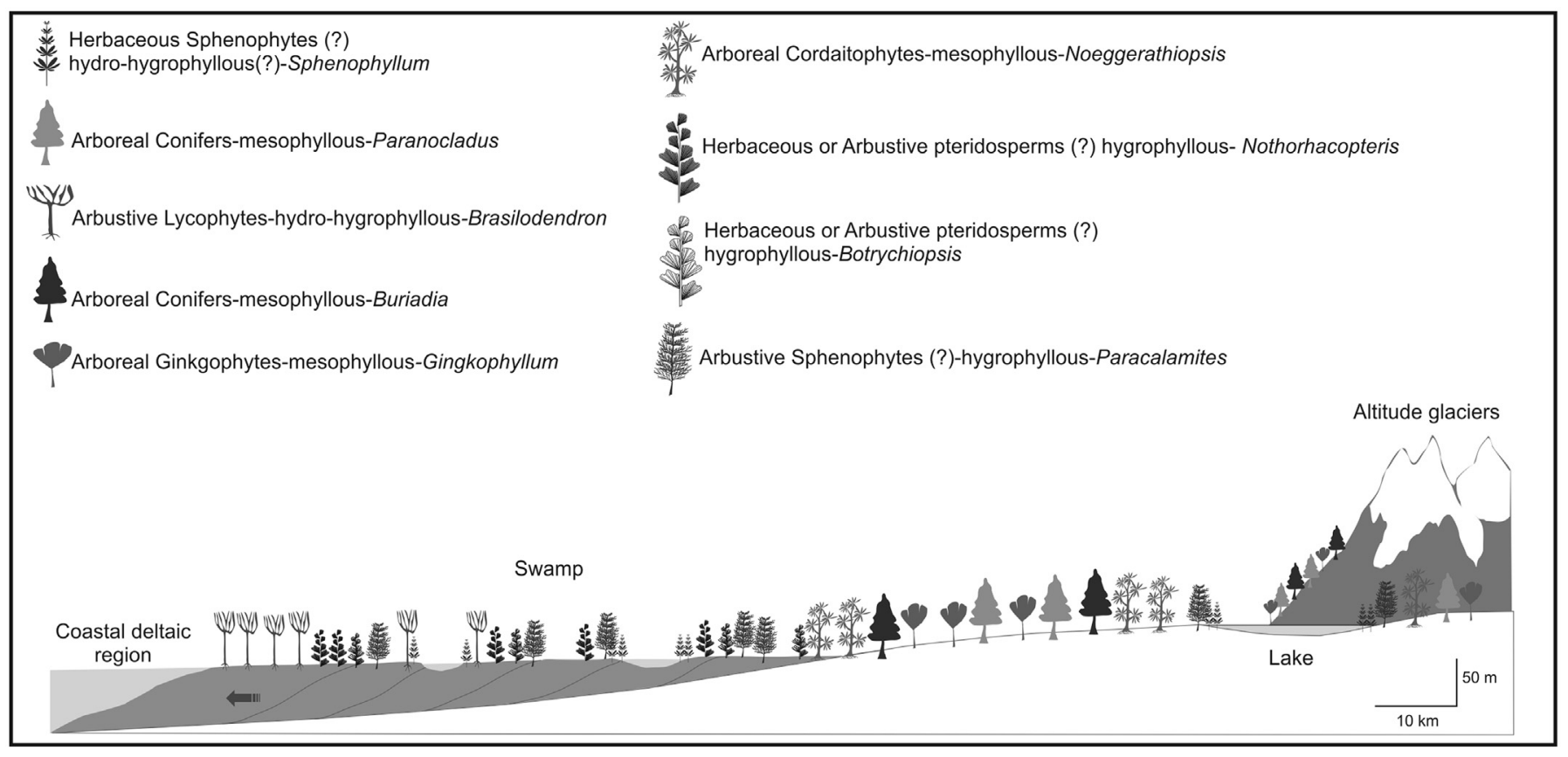

Fig. 10. Reconstruction of the landscape in Monte Mor (SP) during Kasimovian- Gzhelian (modified from R.Rohn personal communication).

Although the PGB association has some species in common with the Argentinean NBG Association, qualitatively the PGB association shares more species in common with the Krauselcladus-Astherotheca Phytozone. Moreover, the first appearance of conifers Voltziales in both the Brazilian PGB association (Paranocladus and Buriadia) and the Argentinean KA Phytozone (Krauselcladus) are also indicative of a better correlation. This correlation corroborates better with the Crucisaccites monoletus Interval Zone palynoflora (CmZ of Souza, 2006) as attributed by Mune (2005) and Jha et al. (2012) based on the presence of Crucisaccites monoletus and Scheuringipollenites maximus thereby assigning a KasimovianGzhelian age to it.

\section{4. aff. Dwykea-Sublagenicula-Calamospora Recurrent Association (DSCRec As)}

\subsubsection{Type - locality}

This association has as taphoflora-type that occurs in the outcrop of the Itarare Group at the km 101.7 of the SP 75 Highway, near the crossing of this route with the SP-308 Highway, in Salto Municipality (State of São Paulo). (see Fig. 1).

\subsubsection{Occurrences}

This association is recognized only in the type-locality.

\subsubsection{Stratigraphic position}

The phytofossiliferous assemblage contains abundant megaspores, some bryophyte leafy gametophytes and palynomorphs. They are recovered from a $0.60 \mathrm{~m}$ of rhythmites intercalated with massive basal medium grained sandstones and covered by breccias and greenish sandy siltstones, situated below thick and deformed massive sandstones and other lithologies. These rhythmites also contain dropped pebbles. Gama et al. (1992a,b) recognized over this sedimentary sequence other rhythmites, diamictites and sandstones including channels of fluvial sandstones.

\subsubsection{Macrofloristic taxonomic content}

The macro remains contain bryophyte leafy gametophytes that have very similar features to those of the Class Bryopsida identified as aff. Dwykea found in the basal association - occurring in the $96 \mathrm{~km}$ of the Bandeirantes Highway (Campinas, SP). These bryophyte macro-remains as in the first mentioned association also occur among a huge amount of lycophyte megaspores and some unidentified stems. Apparently, the macrophyte association could be considered the same of Bandeirantes Highway but its sufficiently distinct palynological content gives to it a younger age (Kasimovian-Gzhelian) of the Crucisaccites monoletus Interval Zone (Souza, 2006). Thus, the best interpretation for this association is of recurrence of a vegetation type of tundra after the end or beginning of another glaciation.

\subsubsection{Palynogical content and age}

The first taphofloristic occurrence was presented by Longhim et al. (2002), which comprised a content of 50 species, of which 26 species are of spores and 23 of pollen grains and 1 species of algae. They include Calamospora hartungiana, Punctatisporites gretensis, P.sp., Retusotriletes sp., Apiculatisporites cf. variornatus, Apiculiretusispora alonsoi, A. tuberculata, Granulatisporites triconvexus, Verrucosisporites morulatus, V. microtuberosus, Dibolisporites disfacies, Raistrickia paganciana, $R$. rotunda, Reticulatisporites pseudopalliatus, Cirratriradites sp., Cristatisporites irradiatus, $C$. stellatus, $C$. morungavensis, Jayantisporites sp., Krauselisporites volkheimeri, Lundbladispora brasiliensis, L. riobonitensis, Vallatisporites arcuatus, V. ciliaris, V. vallatus, Velamisporites sp., Cannanoropolis densus, C. janakki, C. triangularis, Crucisaccites monoletus, Plicatipollenites densus, P. malabarensis, P. trigonalis, Florinites occultus, Potonieisporites novicus, $P$. neglectus, $P$. brasiliensis, $P$. magnus, $P$. methoris, Divarisaccus stringoplicatus, Caheniasaccites flavatus, C. sp., Meristocorpus sp., Scheuringipollenites maximus, Limitisporites rectus, $L$. luandensis, L. hexagonalis, Protohaploxypinus amplus and Botryococcus braunii. This palynological composition led Souza (2006) to attribute these strata to the Crucisaccites monoletes Interval Zone $(\mathrm{CmZ})$, corresponding to the middle part of the Itarare Group, with Westphalian-Stephanian (=Kasimovian-Ghzelian) age, based on the presence of guide species from this zone (C. monoletus and $S$. maximus). 


\subsubsection{Paleoecology}

This phytostratigraphical association suggests shallow fresh to brackish water environment due to the presence of Botryococcus. On the other hand, the macroflora suggests the existence of a typetundra vegetal cover, consisting of bryophyte gametophytes, lycophytes (represented by abundant megaspores) and unidentifiable stems. Pebbles dropped into the rhythmite indicate the glacier proximity and confirm the idea of tundra-type for this type of vegetation, while some pollen grains can be associated to more distant vegetation communities. This association can be related to the beginning or ending of a glaciation around the Kasimovian to Gzhelian, based on palynological data (Souza, 2006).

\subsubsection{General considerations of the aff. Dwykea-Sublagenicula- Calamospora Recurrent Association}

The palynoflora recovered from a rhythmite of the Itarare Group outcropping in the Salto region, São Paulo State aroused particular interest to initiate studies with the view of identifying the biostratigraphic level of the macrofossils of mosses and megaspores discovered in this association. Additionally, this rhythmite presented fallen pebbles, attesting the presence of icebergs and therefore leading to the interpretation of a very cold climate during its deposition. Despite this climate, the palynological analysis revealed relatively high diversity of spores and pollen grains (Longhim et al., 2002). Based on its palynological contents characterizing the Crucisaccites monoletus Interval Zone $(\mathrm{CmZ})$ (Longhim et al., 2002; Souza, 2006), this association is placed in a median chronostratigraphic position of the Itararé Group. From the macrofloral point of view it corresponds to a recurrence of aff. Dwykea-Sublagenicula-Calamospora Association (DSCAs) in superior level when similar periglacial environmental conditions occurred again.

\subsection{Gangamopteris-Arberia-Stephanophyllites Association (GAS} As)

\subsubsection{Type locality}

The taphoflora-type occurs in an outcrop of the "Toca do Índio Ranch" (ex-“Itapema Ranch"), situated $9 \mathrm{~km} \mathrm{SW}$ of the city of Cerquilho (São Paulo State). It is located on the left margin of a stream at the latitude of $23^{\circ} 13^{\prime} 52^{\prime \prime} \mathrm{S}$ and longitude $47^{\circ} 25^{\prime} 24^{\prime \prime} \mathrm{W}$ (Fig. 1).

\subsubsection{Occurrence}

Beyond the "Toca do Índio Ranch" occurrence, other occurrence localities of this association are: a) Taphoflora of the "Bairro Aliança" (former Ranch of the Mine), located at WNW of the city of Cerquilho, next to the Sewerage Treatment Plant. This taphoflora was studied by Millan et al. (1982); b) Taphoflora of the "Lapa of the Coal" of the "Bairro Aliança" occurring next to the old coal mine of the Figueira Velha stream and in a drill core. This taphoflora was studied by Perinotto and Rösler (1987); c) Taphoflora of the "Rio Capivari" occurring to the left margin of the river Capivari (Municipality of Tietê, SP), about $400 \mathrm{~m}$ upstream from the bridge of the old road Piracicaba-Tietê. This outcrop has an extension of more than $100 \mathrm{~m}$ along the margin of the river, toward NE direction, at the coordinates $22^{\circ} 59^{\prime} 3^{\prime \prime} \mathrm{S}$ and $47^{\circ} 45^{\prime} 05^{\prime \prime} \mathrm{W}$, in the altitude of $475 \mathrm{~m}$. This taphoflora was preliminarily described by Rohn et al. (2000).

\subsubsection{Stratigraphic position}

The "Rio Capivari" taphoflora is included in the upper portion of the Itararé Group, being interglacial because, as observed in field by Rohn et al. (2000), in the outcrop, there is a basal diamictite and near the Tietê - Piracicaba old road, there is another outcrop of diamictite about $550 \mathrm{~m}$ after the bridge (toward Tietê). It is topographically and probably stratigraphically at least $40 \mathrm{~m}$ or more above the phytofossiliferous level.

Soares et al. (1977) presented a geological profile carried throughout the Tietê-Piracicaba new road, approximately, parallel to the old road (Fig. 11).

In this profile, an occurrence of plant remains is indicated approximately in the same altitude of the outcrop of the Capivari river (about $475-480 \mathrm{~m}$ ). This occurrence could be registering the last interglacial events of the Paraná Basin, because it is overlapped by diamictite of the Itararé Group and the contact with the Tatuí Formation (= Rio Bonito and/or Palermo formations), documenting the post-glacial phase occurring at the altitude of $\sim 500 \mathrm{~m}$. However the taphoflora- type locality of the "Toca do Indio Ranch", in Cerquilho, SP, is subject of different opinions regarding its lithostratigraphic position. According to Perinotto (1987), Rohn (1987), Fúlfaro et al. (1991), Perinotto (1992) and Perinotto and Fúlfaro (2001), this outcrop would belong to the Tietê Formation or Rio Bonito Formation, with post-glacial character. According to these authors, the lithostratigraphic position and the age of the deposits with plant macrofossils of Cerquilho (Toca do Índio Ranch) was not determined with precision because: a) the lithologies are not characteristic of the Itararé Group, probably belonging to the overlapping unit; b) the outcrop occurs isolated, surrounded by geologic faults, making correlation difficult; c) the samples of the outcrop always resulted barren in palynological terms.

Whereas Nagalli and Consoni (1984), based on interpretation of drill core profiles, considered that the Cerquilho coal is situated in the upper portion of the Itararé Group. Souza Filho (1986) based on sequence stratigraphic analysis concluded that the coal of Cerquilho could be among the mudstones and diamictites of the Unit III. Massoli et al. (1986) observed the presence of rhythmites stratigraphically situated $5 \mathrm{~m}$ above the coal and phytofossiliferous beds of the "ex Itapema ranch". According to Martini and RochaCampos (1991) and Santos et al. (1996), the coal layers of Cerquilho had been the result of deposits in a prograding coastal, alluvial environment included in the Itararé Group. Considering also the sketch of França et al. (1996), the Cerquilho coal could be included in the Chapéu de Sol Member outcropping into the package of diamictites that could be partially correlated to the Rio do Sul Member, comprising fine lithologies occurring in south of the basin. To summarize, it seems that geologically the phytofossiliferous occurrence of the Toca do Indio Ranch, in Cerquilho (SP) is included in the Chapéu de Sol Member (among the diamictites and sandstones), of the lithostratigraphic unit Taciba Formation, superior strata of the Itararé Group.

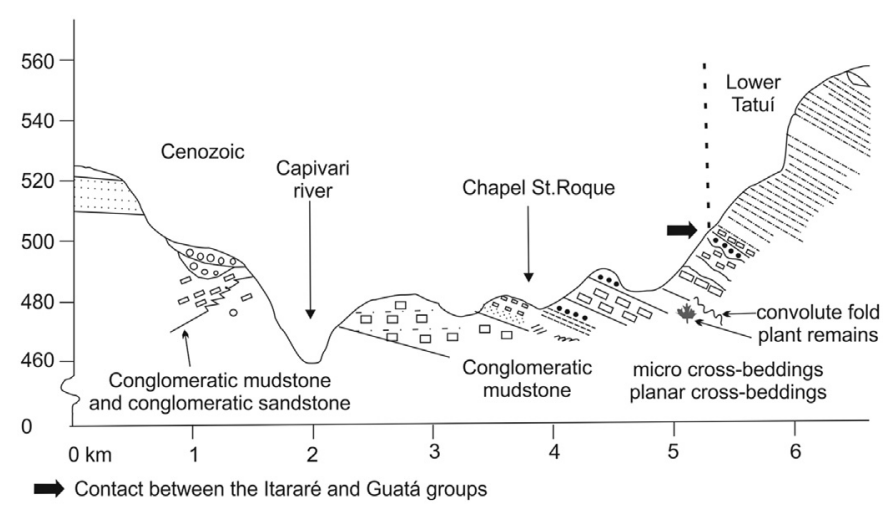

Fig. 11. Geological profile along the Tietê-Piracicaba new road (Soares et al., 1977). 


\subsubsection{Macrofloristic taxonomic contents}

The "Toca do Índio Ranch" occurrence, in Cerquilho (SP), was discovered by Dolianiti and Millan (1973). It was studied by Millan (1977a,b, 1989b, 1991a, 1994 and 1995a,b), Millan and Dolianiti (1977, 1979, 1980a, 1980b, 1981 and 1982), Iannuzzi and Rohn (1995), Ricardi-Branco and Bernardes-de-Oliveira (2000), Rohn and Lages (2000), Bernardes-de-Oliveira et al. (2007) and Hoelzel (2014).

The sphenopsids are represented by four distinct species of three genera (Paracalamites australis, Phyllotheca australis, $P$. sp and Stephanophyllites sanpaulensis). According to Rohn and Lages (2000), the Stephanophyllites sanpaulensis is a taxon exclusive for this association and the sphenopsids are the most common plant macrofossils from the "Toca do Índio" outcrop. The abundance of sphenophytes has been ascertained, but by our observation the forms most characteristic and diversified in this association are the gangamopterids. Initially eight distinct forms of them namely Gangamopteris obovata, G. angustifolia, G. stephensonii, G. dolianitii, G. aff. G. obovata, G. roesleri, G. cf. G. mosesii, G. sp. and G. cf. G.buriadica were identified by Dolianiti and Millan (1973) and Ricardi-Branco and Bernardes-de-Oliveira (2000). Five distinct forms of protoglossopterids were identified as Rubidgea (Rubidgea lanceolata, $R$. lanceolata var. truncata, $R$. itapemensis, $R$. obovata and $R$. sp. (by Millan and Dolianiti, 1982). Later, Hoelzel (2014) recognized six species of Gangamopteris (G. angustifolia, G. buriadica, G. dolianitii, G. obovata, G. roesleri and G. stephensoni) considering all the species of Rubidgea synonymized into Gangamopteris and Tybusch and Iannuzzi (2008) had already done with similar forms of Rubidgea present in the state of Rio Grande do Sul, southern portion of the Parana Basin.

Fructifications like Arberia, Arberiopsis and Hirsutum type (Millan and Dolianiti, 1980b; Bernardes-de-Oliveira et al., 2000) and putative and very rare forms attributed to Glossopteris (Dolianiti and Millan, 1973; Iannuzzi and Rohn, 1995) have their first appearance in this association in the Paraná Basin. Cordaitales are present as Cordaites (Millan and Dolianiti, 1981). Platyspermic seeds such as Samaropsis and Cordaicarpus are also numerous and diversified (Bernardes-de-Oliveira et al., 2007b).

The Table 6 lists the content of taxa of the plant megafossils of the Gangamopteris-Arberia-Stephanophyllites Association, as in its localities of occurrences and the macrofloral composition of this association is given in Fig. 12.

Previously the phytofossiliferous assemblage of "River Capivari "(Tietê, SP) was considered older than that of the "Toca do Índio Ranch" (Cerquilho, SP) based on the following arguments: the first assemblage occurs in the superior portion of the Itarare Group, below the last diamictites and its gangamopteroid foliar forms lack a well marked median veins parallel bundle which is a character less evolved than that of the Toca do Índio taphoflora (Cerquilho, SP) (Rohn et al., 2000). But, considering the few forms collected from River Capivari taphoflora, their bad preservation and the presence of Gangamopteris, Arberia and Ottokaria as in the Toca do Índio Ranch taphoflora, it is tentatively also included in the GAS association.

\subsubsection{Palynological content and age}

For the upper part of Itarare Group and for almost all the Rio Bonito Formation, Souza and Marques-Toigo (2001, 2003, 2005) proposed the Vittatina costabilis Interval Zone divided into two subzones: Protohaploxypinus goraiensis and Hamiapollenites karroensis.

According to Souza (2006), the Vittatina costabilis Interval Zone (VcZ) is "recorded in the northern Paraná Basin, from levels where the occurrences of the genus Vittatina become steady and increase

Table 6

The plant macrofossil taxa of the Gangamopteris-Arberia-Stephanophyllites Association, in its localities of occurrences. (After R.Rohn et al., 2000).

\begin{tabular}{|c|c|c|c|c|}
\hline \multirow[t]{2}{*}{ Taxa } & \multicolumn{4}{|l|}{ Localities } \\
\hline & Toca do Índio Ranch & Rio Capivari & Bairro Aliança & Lapa do carvão B. Aliança \\
\hline cf. Lycopodites sp & $\mathrm{X}$ & & & \\
\hline Paracalamites australis & $\mathrm{X}$ & $\mathrm{X}$ & $\mathrm{X}$ & \\
\hline Phyllotheca australis & $\mathrm{X}$ & Cf. & & \\
\hline Phyllotheca sp A. & & & $\mathrm{X}$ & \\
\hline Stephanophyllites sanpaulensis & $\mathrm{X}$ & $\mathrm{X}$ & & \\
\hline Noeggerathiopsis sp & $\mathrm{X}$ & $\mathrm{X}$ & $\mathrm{X}$ & \\
\hline cf. Fertiliger type Brasilóide & $\mathrm{X}$ & & & \\
\hline Arberia cf. A. minasica & $\mathrm{X}$ & & & \\
\hline A. sp. & $\mathrm{X}$ & & & \\
\hline Arberiopsis sp & $\mathrm{X}$ & & & \\
\hline A. (Samaropsis) rigbyi & $\mathrm{X}$ & & & \\
\hline (?) Hirsutum sp & $\mathrm{X}$ & & & \\
\hline Gangamopteris obovata & $\mathrm{X}$ & $\mathrm{X}$ & & \\
\hline G. angustifolia & $\mathrm{X}$ & cf. & & \\
\hline G. stephensonii & $\mathrm{X}$ & & & \\
\hline G. dolianitii & $\mathrm{X}$ & & & \\
\hline G. aff. G. obovata & & $\mathrm{X}$ & & \\
\hline G. roesleri & $\mathrm{X}$ & & & \\
\hline G. cf. G. mosesii & & $\mathrm{X}$ & & \\
\hline G. sp & & $\mathrm{X}$ & & \\
\hline cf. G. buriadica & & $\mathrm{X}$ & & \\
\hline (?) Glossopteris $\mathrm{sp}($ ?) Glossopteris $\mathrm{sp}$ & $\mathrm{X}$ & & & \\
\hline Cordaicarpus brasilianus & $\mathrm{X}$ & & & \\
\hline Samaropsis rigbyi & $\mathrm{X}$ & $\mathrm{X}$ & & \\
\hline S. dolianitii & $\mathrm{X}$ & & & \\
\hline S. tietensis & $\mathrm{X}$ & & & \\
\hline S. moreirana & $\mathrm{X}$ & & & \\
\hline S. goraiensis & $\mathrm{X}$ & & & \\
\hline S. cerquilhensis & $\mathrm{X}$ & & & \\
\hline S. rohnii & $\mathrm{X}$ & & & \\
\hline S. rugata & $\mathrm{X}$ & & & \\
\hline Roots "in situ" & $\mathrm{X}$ & & & $\mathrm{X}$ \\
\hline
\end{tabular}




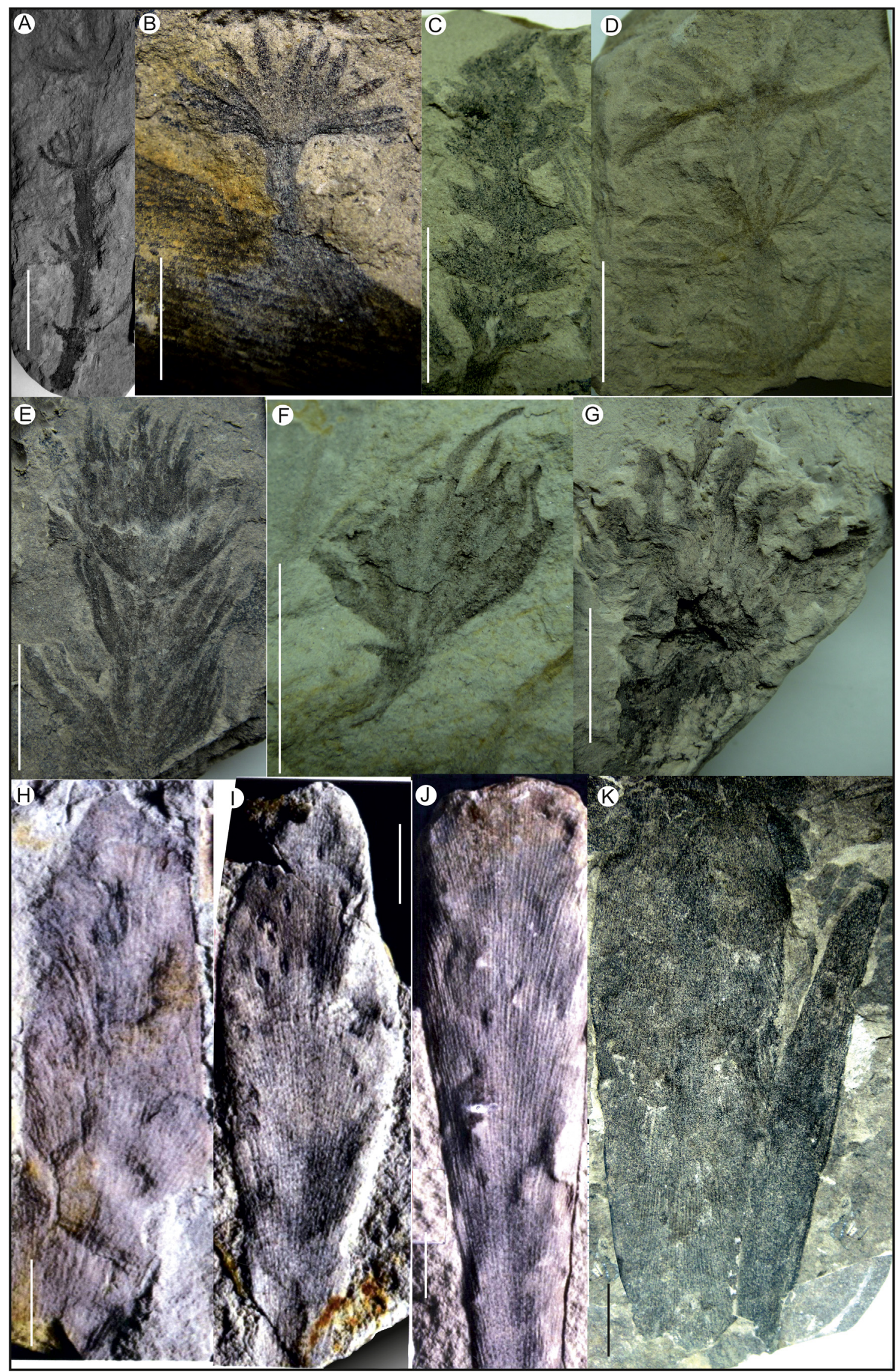

Fig. 12. Macrofloral composition of Gangamopteris-Arberia-Stephanophyllites Association. A, B, D. Phyllotheca australis Brongniart 1828.GP/3E 1629, Figure B.-P/3E 1509, Figure DGP/3E 1527a. C, E and F. Stephanophyllites sanpaulensis Millan and Dolianti 1980 emend Rohn and Lages 2000. GP/3E 1617, Figure E- GP/3E 1497, Figure F-GP/3E 4566. G. Arberia minasica White emend. Rigby 1972.GP/3E 1528a. H, K. Gangamopteris angustifolia Mc Coy 1875.GP/3E 1647, Figure K-GP/3E 1497 I. Gangamopteris obovata (Carr.) White 1908, GP/3E 1611. J. Gangamopteris buriadica Feistmantel 1879.GP/3E 1488 b. 
in frequency". The species Protohaploxypinus goraiensis and Illinites unicus are recognized in the northeastern Paraná Basin, in the uppermost portion of Itararé Group and/or basal portion of Tatuí Formation (Guatá Group) allowing correlation with the P. goraiensis Subzone.

Souza (2006) indicated as outcropping occurrences of this Subzone: Capivari (Daemon, 1974; Arai, 1980), Bairro Aliança in Cerquilho (Lages, 2000; Lages et al., 2002a,b; Souza et al., 2001) and Jumirim-Tietê (Callegari, 2001; Souza and Callegari, 2004). This Subzone would enclose deposits of the upper part of the Itararé Group and the lower part of the Rio Bonito Formation (or equivalents), not presenting resolution to separate the two units. An Asselian- Sakmarian age was attributed to this Subzone.

The most diagnostic taxa of this subzone, after Souza (2006), are taeniate and polyplicate pollen grains: Protohaploxypinus goraiensis, P. amplus, P. limpidus, P. perfectus, Illinites unicus, Vittatina costabilis, V. woodhousei, V. vittifera, V. subsaccata. The monosaccate pollen grains such as Cannanoropollis spp., Plicatipollenites spp. and Potonieisporites spp. are very common. Cingulizonate spores are frequent. According to Souza and Marques-Toigo (2005) " The suggested age for the Vittatina costabilis Zone is based on previous palynological and paleobotanical data (e.g. Daemon and Quadros, 1970; Rösler, 1978) as well as on radiometrical data obtained from correlative Fusacolpites fusus-Vittatina subsaccata Interval Zone of Argentina (Césari and Gutiérrez, 2000, p. 134)".

\subsubsection{Paleoecology}

The environment of deposition for the coal measures of Cerquilho, as registered previously, is interpreted as coastal prograding or alluvial, of an interglacial phase at the end of the sedimentary history of the Itararé Group (Martini and Rocha-Campos, 1991 and Santos et al., 1996).

The early Cisuralian vegetation of Tietê (River Capivari) and Cerquilho (Toca do Índio Ranch and Bairro Aliança) would correspond to hygrophilous communities of Phyllotheca and Stephanophyllites living at the margins of interdistributary channels, in deltaic plains and to communities of type-gangamopteroids as well as Cordaitales (Noeggerathiopsis) living more to the interior of the continent, in fluvial plain environments, or little more raised (mesophilous). A reconstruction of this scenario is illustrated in Fig. 13.

\subsubsection{General evaluation of the Gangamopteris-Arberia- Stephanophyllites Association}

Proto- or Glossopterids are absent in all the associations previously presented. They were Pennsylvanian associations and they were all included in the "A" taphoflora of Rösler (1978) or designated "Pre-Glossopteris Flora" by Iannuzzi and Souza (2005).

The fifth and last level of the Pennsylvanian-Early Cisuralian interglacial macrofloristic succession in the northeastern edge of the Paraná Basin comprises of associations of characteristic plant macrofossils, registering the entrance of the first elements of the Glossopteris Flora in the Paraná Basin as Gangamopteris species. According to Rösler (1978), it constitutes the "Transitional taphoflora" between "A" and "B". It corresponds to the lower portion of Phyllotheca-Gangamopteris flora of Iannuzzi and Souza (2005) restricted to upper strata of Itararé Group.

This association with 32 species of recognized plant megafossils is the most diversified of the five presented. This record evidences that this entrance took place in an interglacial context before the last glacial phase of the Itararé Group, probably corresponding to a temperate cold climate [Rio Capivari taphoflora of Tietê (SP) and Toca do Índio and Bairro Aliança taphofloras of Cerquilho (SP)]. The palynological analysis of the Rio Capivari taphoflora (Tietê, SP) samples carried out by Callegari (2001) and of the Bairro Aliança (Cerquilho, SP) carried out by Lages (2000) include both taphofloras within the Protohaploxypinus goraiensis Subzone of the Vittatina costabilis Interval Zone of Souza and Marques-Toigo (2001). This Subzone would enclose deposits of the upper part of the Itarare Group and the lower part of the Rio Bonito Formation (or equivalents), without resolution to separate the two units. An AsselianSakmarian age was attributed to this Subzone by Souza and Marques-Toigo (2003, 2005) and Souza (2006).

This association, representing the transitional taphoflora sensu

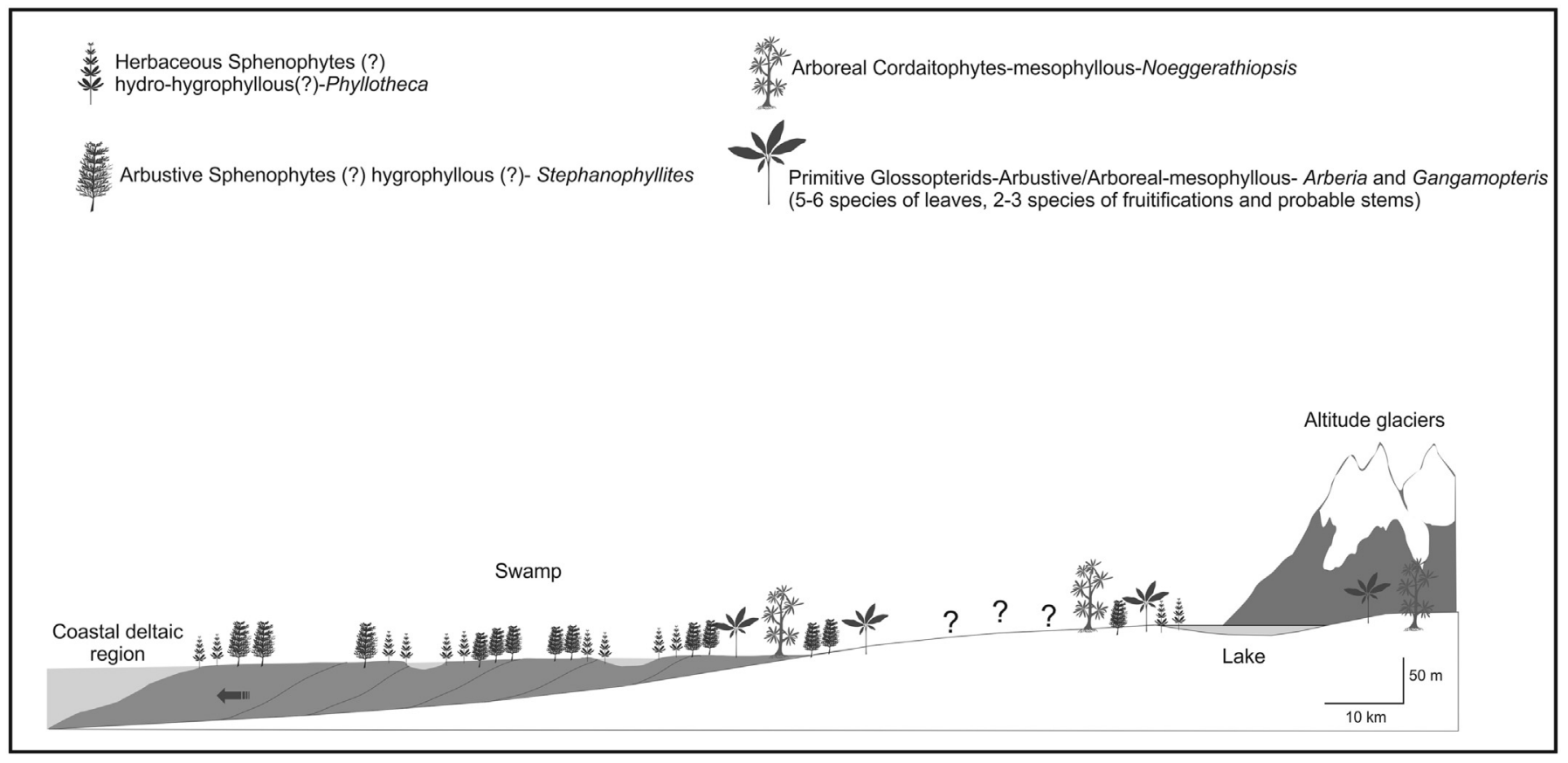

Fig. 13. Landscape scenery in Cerquilho during Asselian- Sakmarian (modified from Rohn Pers. Comm.). 
Rösler (1978), could be correlated with the basal portion of the Gangamopteris obovata Subzone of the Botrychiopsis plantiana Zone of the south of the Paraná Basin sensu Guerra-Sommer and CazzuloKlepzig (1993), with which it presents in common at least four species (Gangamopteris obovata, G. angustifolia, G. buriadica and Noeggerathiopsis hislopii), however, without still presenting well defined elements of the Glossopteris genus, it could be considered slightly older than the Botrychiopsis plantiana Zone. It could also be correlated with the lower part of the Gangamopteris Biozone of the NW of Argentina (sensu Archangelsky and Cúneo, 1991). With this Asselian Biozone, it shares elements such as Phyllotheca sp., Gangamopteris obovata and Noeggerathiopsis hislopii. It differs from the Argentinean flora mainly by the absence of Botrychiopsis plantiana, Paranocladus? fallax, Pecopteris, Glossopteris occidentalis and G. wilsonii. These distinctions could not only be attributed to differences in age but also to paleoecological differences.

Comparing with the Indian phytostratigraphic levels, the Gangamopteris - Arberia - Stephanophyllites Association corresponds probably to the lowermost portion of the Talchir Stage based on the presence of the genus Gangamopteris and absence of the genus Glossopteris. But a diversity of Gangamopteris species is found in Cerquilho, while only one species of Gangamopteris has been recorded in the basal level of the Talchir Stage suggesting that the Cerquilho area could be a dispersion center of the Gangamopterids southwards in the Paraná Basin and also towards the eastern Gondwana towards the Indian basins (Hoelzel, 2014).

\section{Results and discussions}

The northeastern part of Paraná Basin presents one of the oldest floral successions of the Gondwanaland, together with Argentina and Australia. The São Paulo State, in comparison to other parts of the Paraná Basin, hosts one of the most complete sedimentary records of the Gondwana glaciation from the Late Carboniferous to the Early Permian time, thus facilitating greater scope for detailed studies. They correspond to the Itararé Group sediments of the Gondwana I Supersequence. Biostratigraphical studies from a paleobotanical perspective within the State of São Paulo dates back to the pioneering contributions of Rösler (1978), followed by Millan (1987a) and more recently by Bernardes-de-Oliveira et al. (1999, 2000, 2001a, 2001b, 2005).

Considering the Rosler scheme (1978) it is possible to notice that only two phytofossil horizons were known and included in the Itararé Group of the São Paulo State during that time (Table 1). Millan (1987a) expanded the knowledge of the palaeobotanical succession adding Itapeva and Cerquilho occurrences but with many subdivisions of horizons not yet completely known and established (Table 2). Bernardes-de-Oliveira et al. (2005) in an abstract, proposed a new scheme which in this work is detailed and well based. In this work, a formal scheme of the paleofloral succession in the late Paleozoic interglacial sequence occurring in the State of Sao Paulo based on macroflora is proposed, along with some supporting evidences from microfloral and lithostratigraphical data. A very basal interglacial and periglacial associations are recognized just on the border of Paraná Basin- Dwykea-Sublagenicula-Calamospora Association (late Bashkirian- Moscovian) and its recurrence later in Salto distinguished by their different palynological compositions and stratigraphical positions (Kasimovian-Gzhelian, Souza, 2006). The Eusphenopteris-Nothorhacopteris-Botrychiopsis Association (Moscovian), recognized in the south of the State of São Paulo, thrived in a regressive interval forming coalseams. The Paranocladus-Ginkgophyllum-Brasilodendron Association (Kasimovian) in Monte Mor is characterized by the first entrance of conifers in the Paraná Basin. The GangamopterisArberia-Stephanophyllites Association (Asselian-Sakmarian) recognized in the Rio Capivari and Cerquilho is characterized by the entrance of the Glossopteris flora, although the genus Glossopteris is absent it is an important sign for the beginning of Permian in the Paraná Basin.

These associations are supported by palynological studies for the assignment of age and they exhibit a sequence of changes through time from late Bashkirian to Asselian-Sakmarian beginning with a tundra like vegetation which re-occurred probably several times from late Bashkirian to Kasimovian, followed by the appearance of progymnosperms and pteridosperms such as Botrychiopsis, Nothorhacopteris and Eusphenopteris during late Bashkirian to Moscovian, thereafter by the first arrival of conifers in Paraná Basin during Kasimovian to Gzhelian, followed by the first arrival of the elements of the Glossopteris Flora in the basin in the upper strata of the Itararé Group during the Asselian-Sakmarian. Along with these changes, the analysis of the components of each association indicates that a climatic amelioration favored the proliferation of the flora as shown in the fifth association (GAS Association) which is the most diversified than the others. All these associations are included in the Phase $A$ of the paleogeographic studies for Paraná Basin of Christiano-de-Souza and Ricardi-Branco (2015).

This study should not be considered as the final because the area hosts rich palaeobotanical records facilitating further detailed studies which will aid in the enhancement of the existing knowledge in terms of taxonomy and biostratigraphy thus contributing to the establishment of a better framework of the paleofloral succession in this area.

\section{Acknowledgements}

This work is based on the data from the FAPESP Thematic Project 97/03639-8: "Paleofloristic composition and succession survey of the Upper Carboniferous to Lower Permian (Tubarão Supergroup) in the State of São Paulo". The authors are thankful to CNPq Brazil and to the Department of Science and Technology of India for the Indo-Brazilian International Scientific Cooperation Program for the financial grants to the Project CNPq 490829/2007-4 and DST-India RPO-24/2007 both entitled "Paleobotanical Studies on Brazilian and Indian Sedimentary Basins with Special Reference to Marine Dinoflagellate Cysts, Gondwana Flora and their Applications". MECBO, PAS and RI are thankful to CNPq for the Research Productivity Scholarship 304978/2013-2, 310727/2014-6 and 309211/2013-1 respectively. PSK is thankful to the CNPq for the BJT Scholarship (300578/ 2015-6) of the Science without Frontiers Programme,to the Director of the Birbal Sahni Institute of Palaeosciences, Prof. Sunil Bajpai, for the permission to come to Brazil and to the Instituto de Geociências, Universidade de São Paulo, São Paulo for facilities to carry out her Post doctoral studies. MS is thankful to the CNPq for the PDJ Scholarship (150574/2015-0). AJ and PAS thank the CNPq for the Project CNPq numbers 400972/2013-1and 461628/2014-7 respectively. The authors are grateful to the anonymous reviewers for their suggestions which has improved this work.

\section{References}

Amaral, P.G.C. 2000. Estudo da tafoflora do Subgrupo Itararé no afloramento km 96 da Rodovia dos Bandeirantes, Município de Campinas, SP. (Inédito). Graduation Monograph. Instituto de Geociências da USP, São Paulo, p. 39.

Amaral, P.G.C., Ricardi-Branco, F., 2004. Ocorrência de megásporos no Carbonífero Superior (Subgrupo Itararé) na porção NE da bacia do Paraná, Estado de São Paulo. Rev. Bras. Geociências 34 (2), 253-262.

Amaral, P.G.C., Bernardes-de-Oliveira, M.E.C., Ricardi-Branco, F., Broutin, J., 2004. Presencia de Bryopsida fértil en los niveles westfalianos del Subgrupo Itararé, Cuenca de Paraná, Brasil. Trop. Bryol. 25, 101-110.

Amaral, P.G.C., Ricardi-Branco, F., de Souza, P.A., Bernardes-de-Oliveira, M.E.C., 2001. Macro and microphytofossils study of the Itararé subgroup at $\mathrm{km} 96$ of 
Bandeirantes Highway, Campinas municipality, SP. An. Acad. Bras. Cienc. 73 (3), 462

Anderson, J.M., Anderson, H.M., 1985. The Palaeoflora of Southern Africa. Prodromus of Southern African Megafloras Devonian to Lower Cretaceous. Published for the Botanical Research Institute, A.A. Balkema/Rotterdam, p. 423.

Arai, M., 1980. Contribuição dos pólens estriados na bioestratigrafia neopaleozoica da parte nordeste da Bacia do Paraná, vol. 11. Boletim IG, Instituto de Geociências, USP, pp. 125-135.

Archangelsky, S., 1983. Nothorhacopteris, a new generic name for some Carboniferous monopinate fronds of Gondwanaland (Rhacopteris ovata Auct and Pseudorhacopteris Rigby 1973). Rev. Palaeobot. Palynology 38 (3-4), 157-172.

Archangelsky, S., Cúneo, N.R., 1984. Zonación del Pérmico continental de Argentina sobre la base de sus plantas fósiles. $3^{\circ}$ Congreso Latinoamericano de Paleontologia (México). Memoria 143-153.

Archangelsky, S., Cúneo, N.R., 1991. The Neopaleozoic floristic succession from Northwestern Argentina. A new perspective. In: Ulbrich, H., Rocha Cmpos, A.C. (Eds.), Gondwana Seven, Proceedings. Instituto de Geociências, Universidade de São Paulo, São Paulo, pp. 469-481.

Archangelsky, S., Azcuy, C.L., Césari, S.N., González, C.R., Sabattini, N., 1987. Correlación general de biozonas. In: Archangelsky, S. (Ed.), El Sistema Carbonífero en la República Argentina. Academia Nacional de Ciencias, Córdoba, pp. $281-292$.

Azcuy, C.L., Jelin, R., 1980. Las palinozonas del límite Carbónico- Pérmico en la Cuenca Paganzo. In: $2^{\circ}$ Congreso Argentino de Paleontología y Bioestratigrafia y $1^{\circ}$ Congreso Latinoamericano de Paleontología (Buenos Aires 1978), 4. Actas, pp. $51-67$.

Azcuy, C., Beri, A., Bernardes-de-Oliveira, M.E.C., Carrizo, H.A., Pasquo, M., Saraiva, P.B., Gonzalez, C., Iannuzzi, R., Lemos, V.B., Melo, J.H.G., Pagani, A., Rohn, R., Amenabar, C.R., Sabattini, N., Souza, P.A., 2007. Biostratigrafía del Paleozóico Superior de America del Sul: primera etapa de trabajo hacia una nueva propuesta. Asoc. Geol. Argent. 11, 09-65.

Bernardes-de-Oliveira, M.E.C., Castro-Fernandes, M.C., Tewari, R., Ricardi-Branco, F., 2007. Platyspermic seeds from the early permian of Paraná Basin, Brazil. Palaeobotanist 56, 1-19.

Bernardes-de-Oliveira, M.E.C., Ricardi-Branco, F., Rohn, R., Zampirolli, A.P., Lages, L.C., Longhim, M.E., Amaral, P.G.C., 2001a. Sucessão megaflorística do Carbonífero Superior -Permiano Inferior (Grupo Tubarão), Bacia do Paraná, no Estado de São Paulo, Brasil. In: XVII - Congresso Brasileiro de Paleontologia. Boletim de Resumos, Rio Branco, 72-72.

Bernardes-de-Oliveira, M.E.C., Rohn, R., Ricardi-Branco, F., Zampirolli, A. P., Iannuzzi, R., Rosler, O., Longhim, M. E., Lages, L. C., 2000. Revision of the Tubarão Group (Upper Paleozoic) macrofloristic succession, northeastern margin of the Paraná Basin4. In: $31^{\circ}$ International Geological Congress, 2000, Rio de Janeiro. Booth C9-CD.

Bernardes-de-Oliveira, M.E.C., Rohn, R., Ricardi-Branco, F., Zampirolli, A.P., Mune, S.E., Amaral, P.G.C., Longhim, M.E., Castro-Fernandes, M.C., Lages, L.C., 2005. Late carboniferous to early permian glacial related paleofloras from northeastern Paraná Basin, Brazil. In: Gondwana, 12. Academia Nacional de Ciências, Mendoza, 69-69.

Bernardes-de-Oliveira, M.E.C., Rohn, R., Souza, P.A., Ricardi-Branco, F., Rosler, O., Iannuzzi, R., Zampirolli, A.P., 1999. Revision of upper paleozoic phytobiostratigraphy schemes in the northern portion of Paraná Basin, Brazil. In: XIV International Congress on the Carboniferous-permian. Abstract, Calgary, 12-12.

Bernardes-de-Oliveira, M.E.C., Rohn, R., Zampirolli, A.P., Ricardi-Branco, F., Iannuzzi, R., Longhim, M.E., Lages, L.C., Rosler, O., 2001b. Late carboniferousearly permian taphofloras from northeastern Paraná Basin's glacial succession in Brazil and comparisons to the argentine record. In: II Simpósio Argentino Paleozoico Superior. Museu Paleontológico Egidio Feruglio, Trelew, 2-2.

Cabral Jr., M., Motta, J.F.M., 1985. Geologia da Formação Itararé e sua potencialidade para carvão na região de Buri/Itapeva- SP. In: São Paulo. Simpósio Regional de Geologia, 5, vol. 2. Actas. SBG, pp. 459-472.

Callegari, L.M., 2001. Palinologia da porção superior do Subgrupo Itararé na região de Jumirim e Tietê, Estado de São Paulo. Graduation Monography, Instituto de Geociências da USP, São Paulo, p. 52.

Carrizo, H.A., Azcuy, C.L., 2006. Krauselcladus-Asterotheca una Fitozona de Asociación del Carbonífero Tardío tardío reconocida en las Cuencas Paganzo y Río Blanco de Argentina. In: $13^{\circ}$ Simposio Argentino de Paleobotánica y Palinología (Bahía Blanca). Resúmenes, p. 30.

Cazzulo-Klepzig, M., Guerra-Sommer, M., 1985a. Relationship between the taphoflora of the Itararé group, Paraná Basin, south Brazil and the permocarboniferous boundary. In: X Congrès International de Stratigraphie et de Géologie du Carbonifère. Compte Rendu, Madrid, pp. 395-408, 1985.

Cazzulo-Klepzig, M., Guerra Sommer, M., 1985b. Paleofloristic Gondwana succession in the Paraná Basin, Rio Grande do Sul, southern Brazil. In: $6^{\circ}$ Congreso Latinoamericano de Geologia. Ingeominas, Memorias, Bogotá, pp. 177-192.

Césari, S.N., Gutiérrez, P.R., 2000. Palynostratigraphy of upper Paleozoic sequencesin central - western Argentina. Palynology 24, 113-146.

Christiano-de-Souza, I.C., Ricardi-Branco, F.S., 2015. Study of the west Gondwana floras during the late paleozoic: a paleogeographic approach in the Paraná Basin - Brazil. Palaeogeogr. Palaeoclimatol. Palaeoecol. 426, 159-169.

Ciantelli Jr., C.A., Cabral Jr., M., Nakano, S., 1983. Avaliação preliminar das ocorrências de carvão mineral na região de Buri-Itapeva (SP). In: Simpósio Reg. de Geologia, vol. 4. Actas, São Paulo, pp. 353-365.

Cúneo, R., 1986. Ecologia de las floras neopaleozoicas argentinas. In: IV Congreso Argentino de Paleontología y Bioestratigrafía, vol. 1. Actas, pp. 195-204.
Daemon, R.F., 1974. Integração dos resultados palinológicos de fauna e flora das camadas fossilíferas da Bacia do Paraná-Implicações estratigráficas e paleogeográficas. Rev. Unimar 1, 25-40.

Daemon, R.F., Quadros, L.P., 1970. Bioestratigrafia do Neopaleozoico da Bacia do Paraná. In: Congresso Brasileiro de Geologia, vol. 24. Anais... SBG, Brasília, pp. $359-412,2$

Dolianiti, E., Millan, J.H., 1973. Novo afloramento de vegetais gondwânicos no Estado de São Paulo. An. Acad. Bras. Ciências 45 (3/4), 653-654.

Franç, A.B., Winter, W.R., Assine, M.L., 1996. Arenitos Lapa-Vila Velha: um modelo de tratos de sistemas canal-lobos subaquosos rasos sob influência glacial, Grupo Itararé (C-P), Bacia do Paraná. Rev. Bras. Geociências 26 (1), 43-56.

Fúlfaro, V.J., Perinotto, A.J., Barcelos, J.H., 1991. Formação Tietê: o pós-glacial no Estado de São Paulo. In: Simpósio de Geologia do Sudeste, vol. 2. Atas, São Paulo, pp. 397-404. SBG.

Gama Jr., E.G., Perinotto, J.A.J., Ribeiro, H.J.P.S., Padula, E.K., 1992a. Contribuição ao estudo da ressedimentação no Subgrupo Itararé: tratos de fácies e hidrodinâmica deposicional. Rev. Bras. Geociências 22 (2), 228-236.

Gama Jr., E.G., Perinotto, J.A.J., Ribeiro, H.J.S.P., Padula, E.K., 1992b. Contribuição ao estudo da ressedimentação no Subgrupo Itararé: um guia temático de campo. Rev. Bras. Geociências 22 (2), 237-247.

Guerra-Sommer, M., Cazzulo-Klepzig, M., 1993. Biostratigraphy of the southern brazilian neopaleozoic Gondwana sequence: a preliminary palaeobotanical approach. In: Congrès International de Stratigraphie et Géologie du Carbonifère et Permien, 12. Bs. As., 1991, vol. 2. Comptes Rendus, pp. 61-72.

Hoelzel, A., 2014. Revisão da Tafoflora Interglacial de Cerquilho (SP), porção superior do Grupo Itararé, Eocisuraliano da borda nordeste da Bacia do Paraná: O gênero Gangamopteris McCoy, 1860. Instituto de Geociências, Universidade de São Paulo, São Paulo, p. 97. Master Degree Dissertation.

Iannuzzi, R., 2001. Significado Bioestratigráfico dos megafósseis vegetais da flora de Monte-Mor, estado de São Paulo, sudeste do Brasil (Subgrupo Itararé, Grupo Tubarão, Bacia do Paraná). In: XVII Congresso Brasileiro de Paleontologia, Boletim de Resumos, p. 68-68.

Iannuzzi, R., Rohn, R., 1995. Discussão sobre a presença do gênero Glossopteris na tafoflora Cerquilho (Grupo Tubarão, Bacia do Paraná, Estado de São Paulo) e seu possível significado biocronoestratigráfico. In: Kellner, A.W.A., Viana, C.F. (Eds.) XIV Congresso Brasileiro de Paleontologia XIV Ata...Uberaba. Sociedade Brasileira Paleontologia, pp. 62-63.

Iannuzzi, R., Souza, P.A., 2005. Floral succession in the lower permian deposits of the brazilian Paraná Basin: an up-to-date overview. N. M. Mus. Nat. Hist. Sci. Bull. 30, 144-149.

Iannuzzi, R., Souza, P.A., Holz, M., 2007. Lower permian post-glacial succession in the southernmost brazilian Paraná Basin: stratigraphic and floral (macro and micro) record. In: Diaz-Martinez, E., Rábano, I. (Eds.), $4^{\text {th }}$ European Meeting on the Palaeontology and Stratigraphy of Latin America. Cuadernos del Museo Geominero $n^{0} 8$. Instituto Geológico y Minero de España, Madrid, pp. 207-212.

Isbell, J.L., Henry, L.C., Gulbranson, E.L., Limarino, C.O., Fraiser, M.L., Koch, Z.J., Ciccioli, P.L., Dineen, A.A., 2012. Glacial paradoxes during the late Paleozoic ice age: evaluating the equilibrium line altitude as control on glaciation. Gondwana Res. 22, 1-19.

Jha, N., Mune, S.E., Bernardes-de-Oliveira, M.E.C., 2012. Palynostratigraphic considerations on the pennsylvanian interglacial microflora from Monte mor (SP) Itararé group, NE Paraná Basin (Brazil) and its diachronic correlation with indian Gondwana microflora. Palaeobotanist 61, 43-55.

Lages, L.C., 2000. Palinologia da porção basal do Grupo Guatá, Supergrupo Tubarão (Permiano Inferior) na região de Cerquilho, Sp. Rio Claro: inédito (Trabalho de Graduação, Instituto de Geociências e Ciências Exata, Unsep), p. 50.

Lages, L.C., Rohn, R., Castro, J. C., Souza, P. A., 2002a. Palinologia da Porção Basal do Grupo Guatá, Supergrupo Tubarão (Permiano Inferior) na Região de Cerquilho,

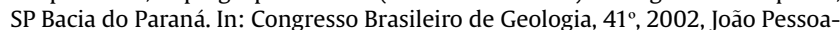
PB. p. 383.

Lages, L.C., Rohn, R., Castro, J.C., Souza, P.A., 2002b. Palinologia da porção basal do Grupo Guatá, Supergrupo Tubarão (Permiano Inferior) na região de Cerquilho, SP - bacia do Paraná. In: 41. Congresso Brasileiro de Geologia. Anais, vol. 1. SBG, João Pessoa, 383-383.

Longhim, M.E., 2003. Palinologia do Grupo Itararé em Salto, Estado de São Paulo (Bacia do Paraná, Carbonífero superior). Master Dissertation. Universidade Estadual Paulista Júlio de Mesquita Filho, UNESP, Brasil.

Longhim, M.E., Souza, P.A., Rohn, R., 2002. Palinologia do Grupo Itararé na região de Salto (Carbonífero Superior), Estado de São Paulo, Brasil. Parte 1- Palinologia sistemática. Rev. Univ. Guarulhos (Geociências) 7 (6), 43-60.

Martini, I.P., Rocha-Campos, A.C., 1991. Interglacial and early post-glacial Lower Gondwana coal sequences in the Paraná Basin. In: Ulbrich, $\mathrm{H}$ and RochaCampos, A.C., 7th International Gondwana Symposium, São Paulo, 317-336.

Massoli, M., Azevedo, A.A.B., Oda, G.H., Santoro, J., Tominaga, L.K., Petri, S., 1986. Contribuição à geologia do Município de Cerquilho, SP. Rev. IG 7 (1/2), $17-30$.

Millan, J.H., 1972. Macroflórula Carbonífera de Monte Mor, Estado de São Paulo. Tese de Doutoramento. IGC/USP, São Paulo, p. 165.

Millan, J.H., 1974. Sobre as Coniferopsida da flórula gondwânica de Monte Mor Estado de São Paulo, Brasil. Ameghiniana 11 (2), 124-134.

Millan, J.H., 1975. Tafoflórula Monte Mor do Estado de São Paulo: seus elementos e seu significado no Gondwana Inferior do Brasil. Rev. Bras. Geociências 5 (1), $1-14$.

Millan, J.H., 1977a. Moldes medulares da tafoflora gondwânica de Monte Mor Estado de São Paulo. An. Acad. Bras. Ciências 49 (1), 195-204.

Millan, J.H., 1977b. Sementes platispérmicas do Eogondwana de Cerquilho, São 
Paulo (Bacia do Paraná). An. Acad. Bras. Ciências 49 (4), 581-595.

Millan, J.H., 1979. Rhacopteris e Botrychiopsis no Eogondwana de Monte Mor, Subgrupo Itararé do Estado de São Paulo. An. Acad. Bras. Ciências 51 (1), 109-120.

Millan, J.H., 1980a. Sobre uma possível utilização estratigráfica de sementes gondwânicas. An. Acad. Bras. Ciências 52 (2), 353-358.

Millan, J.H., 1980b. Lepidodendrales do Eogondwana de Monte Mor, SP, base do Subgrupo Itararé. 1- Brasilodendron pedroanum (Carruthers) Chaloner, Leistkow and Hill, 1979, 11. Boletim IG- USP, pp. 105-113.

Millan, J.H., 1981a. Sobre a presença de Sphenophyllales no eogondwana de Monte Mor, Subgrupo Itararé de Estado de São Paulo. In: Congresso Latino-Americano de Paleontologia $2^{\circ}$, vol. 1. Anais, Porto Alegre, RS, pp. 113-126.

Millan, J.H., 1981b. Sobre a presença de folhas cf. Ginkgophyllum no Eogondwana de Monte Mor, Subgrupo Itararé do Estado de São Paulo, vol. 39. Boletim do Museu Nacional, n.s, Geologia, p. 12.

Millan, J.H., 1985. Lepidodendrales do Eogondwana de Monte Mor, SP, base do Subgrupo Itararé. 2- Sobre o gênero Lepidodendron Stern. In: Campos, D. A. and others (Eds). Coletânea de trabalhos de paleontológicos. DNPM Série Geologia 27, Seção Paleontologia e Estratigrafia, n.2, 613-617.

Millan, J.H., 1987a. Os pisos florísticos do carvão do Subgrupo Itararé no Estado de São Paulo e suas implicações. In: Congresso Brasileiro de Paleontologia, vol. 10. Anais, SBP, Rio de Janeiro, pp. 832-857.

Millan, J.H., 1987b. Descoberta de frondes de Bothrychiopsis plantiana no Eogondwana do município de Itapeva, Subgrupo Itararé do Estado de São Paulo. In: Congresso Brasileiro de Paleonotologia, 10. Anais, Rio de Janeiro, pp. 809-829. SBP, 2.

Millan, J.H., 1989a. Sobre as Sphenopsida da tafoflórula do Eogondwana do Município de Itapeva, carvão do Subgrupo Itararé do Estado de São Paulo. An. Acad. Bras. Ciências 61 (4), 479 (Resumos das communicações).

Millan, J.H., 1989b. Sobre a presença de formas foliares mais primitivas de glossopterídeas (gênero Gangamopteris) no Município de Cerquilho, carvão do Eogondwana do Estado de São Paulo. An. Acad. Bras. Ciências 61 (2), 201-213.

Millan, J.H., 1991a. Novas ocorrências de sementes platispérmicas nos municípios de Itapeva, SP, e Cerquilho, SP, em tafofloras do Grupo Tubarão, Eogondwana da Bacia do Paraná. An. Acad. Bras. Ciências 63 (1) 96.

Millan, J.H., 1991b. Sobre as Sphenopsida de tafoflora associada a camadas carbonosas do Subgrupo Itararé, Eogondwana da Bacia do Paraná, no Município de Itapeva, SP. Bras. An. Acad. Bras. Ciências 63 (3), 229-245.

Millan, J.H., 1993. Sobre as cordaitales da tafoflora eogondvânica de Itapeva, SP, Subgrupo Itararé da Bacia do Paraná, Brasil. An. Acad. Bras. Ciências 65 (2), 213 (Resumos das communicações).

Millan, J.H., 1994. Sobre a ocorrência rara de "Scale-leaves" na tafoflora de Cerquilho, SP, Formação Teitê do Grupo Tubarão da Bacia do Paraná. An. Acad. Bras. Ciências 66 (1), 118 (Resumos das communicações).

Millan, J.H., 1995a. Novas ocorrências de sementes platispérmicas em tafofloras associadas a camadas carbonosas do Grupo Tubarão, Eogondwana da Bacia do Paraná. An. Acad. Bras. Ciências 67 (1), 117-128.

Millan, J.H., 1995b. Ocorrência de Nothorhacopteris na Tafoflora de Itapeva, SP, Subgrupo Itararé (C) da Bacia do Paraná. An. Acad. Bras. Ciências 67 (3), 384 (Resumos das communicações).

Millan, J.H., Dolianiti, E., 1977. Esfenófitas do Eogondwana de Cerquilho, São Paulo (Bacia do Paraná). 1-Gênero Paracalamites. An. Acad. Bras. Ciências 49 (3) 469-477.

Millan, J.H., Dolianiti, E., 1979. Esfenófitas do Eogondwana de Cerquilho, São Paulo (Bacia do Paraná). 2-Gênero Phyllotheca. Bol. Asoc. Latinoam. Paleobot. Palinol $6,1-4$.

Millan, J.H. and Dolianiti, E., 1980a. Esfenófitas do Eogondwana de Cerquilho, São Paulo (Bacia do Paraná). 3-Gênero Stephanophyllites gen. nov. II Congreso Argentino Paleontología Bioestratigrafía y I Congreso Latinoamericano Paleontología, Buenos Aires 1978, Actas, 4: 113-127.

Millan, J.H. and Dolianiti, E., 1980b. Sobre um novo "fertiliger" no Eogondwana de Cerquilho, São Paulo (Bacia do Paraná). II Congreso Argentino Paleontología Bioestratigrafía y I Congreso Latinoamericano Paleontología, Buenos Aires 1978 . Actas 4: 129-137.

Millan, J.H., Dolianiti, E., 1981. Cordaitales do Eogondwana de Cerquilho, São Paulo (Bacia do Paraná). An. Acad. Bras. Ciências 53 (4), 807-815.

Millan, J.H., Dolianiti, E., 1982. Sobre a presença do gênero Rubidgea no Eogondwana de Cerquilho, Subgrupo Itararé de São Paulo, vol. 13. Boletim IG-USP pp. 43-134.

Millan, J.H., Dolianiti, E., Andrade, A.B., 1982. Uma nova tafoflórula no Eogondwana de Cerquilho, Subgrupo Itararé de São Paulo. An. Acad. Bras. Ciências 54 (2), 419-428.

Mune, S.E., 2005. Tafoflora interglacial neocarbonífera do Sítio Volpe, Município de Monte Mor (SP), Subgrupo Itararé, nordeste da Bacia do Paraná: revisão complementação. Master Degree Dissertation. Instituto de Geociências, Universidade de São Paulo, p. 137.

Mune, S.E., Bernardes-de-Oliveira, M.E.C., 2007a. Paleoflorística e bioestratigrafia da tafoflora de Monte Mor (SP), Subgrupo Itararé, NE da Bacia do Paraná. In: Carvalho, I.S., et al. (Eds.), Paleontologia Cenários de Vida, Editora Interciência, vol. 1, pp. 71-82.

Mune, S.E., Bernardes-de-Oliveira, M.E.C., 2007b. Revisão da tafoflora interglacial neocarbonífera de Monte Mor, SP (Subgrupo Itararé), nordeste da Bacia do Paraná. Rev. Bras. Geociências 37 (3), 427-444.

Mune, S.E., Bernardes-de-Oliveira, M.E.C., Tewari, R., 2012a. Upper pennsylvanian lycopsids from interglacial taphoflora of Itararé group, Paraná Basin, Brazil. Palaeobotanist 61 (1), 27-42.
Mune, S.E., Tewari, R., Bernardes-de-Oliveira, M.E.C., 2012b. Pennsylvanian megaspores from northeastern border of the Paraná Basin: correlation with Indian Gondwana megaspores. Palaeobotanist 61 (1), 1-26.

Nagalli, J.T., Consoni, J.O., 1984. Comportamento faciológico do intervalo que encerra as camadas de carvão, na região de Cerquilho, SP. In: Congresso Brasileiro de Geologia, Anais, 33. SBG, Rio de Janeiro, pp. 974-982 vol. 2.

Petri, S., Souza, P.A., 1993. Síntese dos conhecimentos e novas concepções sobre a bioestratigrafia do Subgrupo Itararé, bacia do Paraná, Brasil. Rev. Inst. Geol. São Paulo 14 (2), 7-18.

Perinotto, J.A.de J., 1987. Análise estratigráfica de seqüência portadora de carvão na região de Cerquilho (SP). Dissertação de Mestrado. IGc-USP, São Paulo, p. 76.

Perinotto, J.A.J., 1992. Análise Estratigráfica da Formação Palermo (P) na Bacia do Paraná, Brazil. Tese do Doutorado. Instituto de Geociências e Ciências Exatas da Universidade Estadual Paulista, Rio Claro, p. 126.

Perinotto, J.A.J., Fúlfaro, V.J., 2001. Depósitos de carvão permianos pós-glaciais da Bacia do Paraná no Estado de São Paulo, Brasil. Rev. Univ. Guarulhos- Geociências 6 (6), 56-63.

Perinotto J.A. de.J. and Rösler O., 1987. Raízes fósseis na lapa do carvão de Bairro Aliança (Cerquilho, SP) e Mato Seco (Cesario Lange, SP). X Congresso Brasileiro de Paleontologia, Anais, p. 237-251.

Rees, P.M., Gibbs, M.T., Ziegler, A.M., Kutzbach, J.E., Behling, P.J., 1999. Permian climates: evaluating model predictions using global paleobotanical data. Geology 27, 891-894.

Rees, P.M., Ziegler, A.M., Gibbs, M.T., Kutzbach, J.E., Behling, P.J., Rowley, D.B., 2002. Permian phytogeographic patterns and climate data/model comparisons. Geology $110,1-31$

Ricardi-Branco, F., Bernardes-de-Oliveira, M.E.C., 2000. Gangamopteris roesleri sp. nov. da tafoflora permiana de Cerquilho (SP), Grupo Tubarão, Bacia do Paraná, Brasil. Rev. Univ. Guarulhos - Geociências 44-48.

Rocha-Campos, A.C., Rosler, O., 1978. Late Paleozoic Faunal and Floral Successions in the Paraná Basin, Southeastern Brazil, vol. 9. Boletim IG/USP, pp. 1-16.

Rohn, R., 1987. A flora de Glossopteris. primitive de Cerquilho Velho, Formação Tietê, Permiano Inferior, Cerquilho, SP, Brasil. Guia de Excursão. Bol. La Asoc. Latinoam. Paleobot. Palinol. 8 (1), 25-30.

Rohn, R., Lages, L.C., 2000. Lower permian sphenopsids from Cerquilho, northeastern Paraná Basin, Brazil. Rev. Paléobiol. 19 (2), 359-379.

Rohn, R., Longhim, M.E., Bernardes de Oliveira, M.E.C., Navarro, G.R.B., 2000. Nova ocorrência fitofossilífera neocarbonífera-eopermiana do Subgrupo Itararé à margem esquerda do rio Capivari, Município de Tietê, SP, Brasil. Rev. Univ. Guarulhos, Geociências 57-61.

Rösler, O., 1978. The Brazilian Eogondwanic Floral Successions, vol. 9. Boletim IGUSP, pp. 85-91.

Santos, P.R., Rocha-Campos, A.C., Canuto, J.R., 1996. Patterns of late paleozoic deglaciation in the Paraná Basin, Brazil. Rev. Palaeogeogr. Palaeoclimatol. Palaeoecol. 125, 165-184.

Scotese, C.R., 2000. Paleogeographic Maps (Paeomaps Project). www.scotese.com.

Silva, E.L. da, 1994. Análise estratigráfica do Subgrupo Itararé (P - C), na região de Buri-Itapeva (SP). Master Dissertation. UNESP, Rio Claro, SP.

Soares, P.C., Landim, P.M.B., Fúlfaro, V.J., 1977. Tectonic cycles and sedimentary sequences in the Brazilian intracratonic basins. Geol. Soc. Am. Bull. Boulder 89 (2), 181-191, 1978

Souza Filho, E.E., 1986. Mapeamento faciológico do Subgrupo Itararé na quadrícula de Campinas (SP). Master Degree Dissertation. Instituto de Geociências, Universidade de São Paulo, p. 121

Souza, P.A. 1996. Palinologia e bioestratigrafia do Subgrupo Itararé em Araçoiaba da Serra (Westphaliano, Bacia do Paraná) Estado de São Paulo, Brasil. Master Degree Dissertation. Instituto de Geociências, Universidade de São Paulo.

Souza, P.A., 2000. Palinobioestratigrafia do Subgrupo Itararé, Carbonífero/Permiano, na porção nordeste da Bacia do Paraná (SP/PR, Brasil). Doctoral Thesis. Instituto de Geociências, Universidade de São Paulo.

Souza, P.A., 2003. New palynological data of the Itararé subgroup from the Buri coal (late carboniferous, Paraná Basin) São Paulo state, Brazil. Rev. Bras. Paleontol. 5, 49-58.

Souza, P.A., 2006. Late carboniferous palynostratigraphy of the Itararé subgroup, northeastern Paraná Basin, Brazil. Rev. Palaeobot. Palynol. 138, 9-29.

Souza, P.A., Callegari, L.M., 2004. An early permian palynoflora from the Itararé subgroup, Paraná Basin, Brazil. Rev. Española Micropaleontol. 36, 439-450.

Souza, P.A., Marques-Toigo, M., 2001. Macro palinoestratigráfico do Permiano Inferior da Bacia do Paraná. Ciência-Técnica-Petróleo. Seção Exploração Petróleo 20, 153-159.

Souza, P.A., Marques-Toigo, M., 2003. An overview on the palynostratigraphy of the upper paleozoic strata of the brazilian Paraná Basin. Rev. Mus. Argent. Ciencias Nat. 205-214. Nueva Serie 5.

Souza, P.A., Marques-Toigo, M., 2005. Progress on the palynostratigraphy of the permian strata in Rio Grande do Sul state, Paraná Basin. Braz. An. Acad. Bras. Cienc 77, 353-365.

Souza, P.A., Amaral, P.G.C., Bernardes-de-Oliveira, M.E.C., 2006. A late carboniferous palynoflora from the Itararé subgroup (Paraná Basin) in Campinas, São Paulo state, Brazil. Révue Micropaléontol. 49, 105-115.

Souza, P.A., Félix, C.M., Pérez-Aguilar, A., Petri, S., 2010. Pennsylvanian palynofloras from the Itu rhythmites (Itararé subgroup, Paraná Basin) in São Paulo state, Brazil. Révue Micropaléontol. 53, 69-83.

Souza, P.A., Lages, L.C., Rohn, R., 2001. New palynological data from the Alianca coal mine (Cerquilho, São Paulo state), upper paleozoic Tubarão group, northeastern Paraná Basin, Brazil. In: II Simpósio Argentino sobre El Paleozoico Superior. 
Resúmenes, Trelew, 27-27.

Souza, P.A., Lima, M.R. Saad, A.R., 1993. Palinologia dos carvões paleozoicos do Estado de São Paulo, Brasil. I O carvão de Buri. Rev. do Inst. Geol. 14 (1), 5-20.

Souza, P.A., Saad, A.R., Lima, M.R., 1997. Palinologia dos carvões paleozoicos do Estado de São Paulo II O carvão de Monte Mor. Rev. do Inst. Geol. 18 (1/2), 7-21.

Torsvik, T.H., Cocks, L.R.M., 2013. Gondwana from top to base in space and time. Gondwana Res. 24 (3-4), 999-1030.

Tybusch, G.P., Iannuzzi, R., 2008. Reavaliação taxonômica dos gêneros Gangamopteris e Rubidgea, Permiano Inferior da Bacia do Paraná, Brasil. Rev. Bras. Paleontol. 11, 59-68.

Tyson, R.V., 1995. Sedimentary Organic Matter: Organic Facies and Palynofacies. Chapman and Hall, London, p. 615.

Wnuk, C., 1996. The development of floristic provinciality during the middle and late. Paleozoic. Rev. Palaeobot. Palynol. 90, 5-40.

Zampirolli, A.P., 2001. Tafoflora Neocarbonífera da Fazenda Santa Marta, interglacial do Subgrupo Itararé, Grupo Tubarão, Bacia do Paraná, região de Itapeva (SP), Brasil. São Paulo. Master Degree Dissertation. Instituto de Geociências da USP, p. 131.
Zampirolli, A.P., Bernardes-de-Oliveira, M.E.C., 2001. O gênero Paracalamites Zalessky 1927, na tafoflora de Itapeva, Carbonífero Superior do Subgrupo Itararé, Grupo Tubarão, sudoeste do Estado de São Paulo, Brasil. Revista do Instituto Geológico, São Paulo 21 (1/2), 7-15.

Zampirolli, A.P., Bernardes-de-Oliveira, M.E.C., Souza, P.A., 1999a. Esfenópsida equisetaleana $\mathrm{cf}$. Koretrophyllites sp., na tafoflora neocarbonífera do Subgrupo Itararé, Bacia do Paraná, no municipio de Itapeva, SP, Brasil. Rev. Univ. Guarulhos-Série Geociências IV (6), 96-101.

Zampirolli, A.P., Bernardes-de-Oliveira, M.E.C., Souza, P.A.,1999b. Levantamento da composição e sucessão paleoflorísticas do Neocarbonífero- Eopermiano (Grupo Tubarão) no Estado de São Paulo. II-1- Considerações sobre a tafoflora de préglossopterídeas de Itapeva, Subgrupo Itararé, Bacia do Paraná, Brasil. In: XVI Congresso Brasileiro de Paleontologia, 1999. Boletim de Resumos, Crato, pp. $127-128$.

Zampirolli, A.P., Souza, P.A., Bernardes-de-Oliveira, M.E.C., 2000. Assembléias palinologica neocarbonífera da Tafoflora de Itapeva (SP), Subgrupo Itararé, Bacia do Paraná, Brasil. Rev. Univ. Guarulhos, Geociências 5, 247 (número especial). 